\title{
Effect of electrical conditions on an impedimetric immunosensor based on a modified conducting polypyrrole
}

\author{
Imen Hafaid $^{\mathrm{a}, \mathrm{b}^{*}}$, Syrine Chebil ${ }^{\mathrm{c}}$, Hafsa Korri-Youssoufi ${ }^{\mathrm{c}}$, François Bessueille ${ }^{\mathrm{a}}$, Abdelhamid \\ Errachid $^{\mathrm{a}}$, Zina Sassi ${ }^{\mathrm{b}}$, Zulfiqur Ali ${ }^{\mathrm{d}}$, Adnane Abdelghani ${ }^{\mathrm{e}}$, Nicole Jaffrezic-Renault ${ }^{\mathrm{a}}$ \\ ${ }^{a}$ University of Lyon, Laboratory of Analytical Sciences, UMR-CNRS 5180, Claude Bernard University, Lyon I, 43 \\ Boulevard du 11 Novembre 1918,69622 Villeurbanne Cedex, France \\ ${ }^{\mathrm{b}}$ Ampere Laboratory, Bât L. De Vinci - INSA -20, avenue Albert Einstein, F-69621, Villeurbanne Cedex, France \\ ${ }^{c}$ Equipe de Chimie Bioorganique et Bioinorganique, ICMMO, UMR-CNRS 8182, Paris-Sud University, Bât 420, \\ 91405 Orsay France \\ ${ }^{\mathrm{d}}$ University of Teesside Middlesbrough Tees Valley TS1 3BA UK \\ ${ }^{e}$ Unité de Recherche de Physique des Semi-conducteurs et Capteurs, IPEST, La Marsa, 2070, Tunis, Tunisia
}

\begin{abstract}
This work has explored the development of impedimetric immunosensors based on a conducting copolypyrrole film to which a histidine tag antibody has been bound using a complex NTA chelator coordinated with copper as metal. The electrical properties of the copolymer film have been characterized by Electrochemical Impedance Spectroscopy (EIS). The experimental study of EIS was performed over a range of dc voltages from 0 to $-1.4 \mathrm{~V}$ (vs saturated calomel electrode SCE) where the polypyrrole layers transit from their conducting to insulating state and to demonstrate the contribution of the copper complex as redox probe. The electrical behavior of the biomaterial at these various potentials was studied according to an equivalent circuit fitting the experimental parameters. The results indicated that better immunosensor characteristics were obtained at an applied potential of $1400 \mathrm{mV}$ where the reduction of copper occurs. The impedance obtained at this potential shows a linear variation of charge transfer resistance $\left(R_{\mathrm{ct}}\right)$ with the specific antigen concentration in the range of $0.1 \mathrm{ng} \mathrm{mL}^{-1}$ to $10 \mathrm{ng} \mathrm{mL}^{-1}$ with a detection limit of $0.1 \mathrm{ng} \mathrm{mL}{ }^{-1}$. Moreover, this study demonstrates that these immunosensors exhibit high sensitivity, stability and reproducibility.
\end{abstract}

Key words: Immunosensors, Conducting polymer, impedance spectroscopy, His-tag antibody 


\section{Introduction}

Immunosensors have generated great interest with expectation of providing fast and highly sensitive immunological response. Immunosensors have widespread applications in clinical diagnostics, food safety and quality control, biological analysis and environmental monitoring [1-4]. In recent past years, research in this field has evolved quickly with the aim of improving the performance of the biosensors (specificity, stability, sensitivity, detection limit). Recent studies have focused on the use of conducting polymers as tools for amplification of the response signal from antibody - antigen interactions, which leads to the improvement of the performance characteristics of the biosensor [5,6].

Generally, in physics, conducting polymers are of great scientific and technological importance because of their electrical, electronic, magnetic, and optical properties [7-9]. These beneficial material properties mean that conducting polymers have wide utility in various applications such as anti-static and anti-corrosion coating, batteries and super capacitors, and more recently light emitting diodes (LEDs), electrochromic devices and transparent electrode materials [10-13]. Furthermore, the intrinsic characteristics of conducting polymers allow their exploitation for the preparation of nanocomposites with entrapped nano-scaled biomolecules, mainly proteins [14] and single stranded DNA oligomers [15]. Some conducting polymers doped and/or covalently or non covalently modified by bionanomaterials exhibit unique catalytic or affinity properties that can be easily applied in the design of bioanalytical sensors $[6,16]$. Polypyrrole (PPy) is one of the most extensively studied for the design of bioanalytical sensors. It is attractive because of its good biocompatibility as polymer in vivo [17,18], high electrical conductivity, good redox properties and long-term environmental stability [19, 20]. PPy is widely considered as an effective material for immobilization of biomaterials and for transducing /amplification of analytical signal within immunosensing devices [18,21].

The immobilization of bioactive macromolecules in or on electrically conductive polymers has been extensively explored in an effort to provide intimate contact between these two elements [22]. In fact, the immobilization of biologically active molecules on a conducting 
polymer can be achieved by three methods [23,24]: (i) entrapping biomolecules in an electropolymerized film formed with a mixture of monomers and biomolecules; however, a possible drawback is the denaturation of the molecules (ii) electrostatic binding of biomolecules directly onto specific groups generated on the substrate surface, which constitutes a convenient method for immobilizing proteins; however, the major drawback of this method is the strength of interaction, which is dependent on the surrounding solution, and so changes in ionic strength and/or in $\mathrm{pH}$ can cause the release of the attached moiety; and (iii) covalent attachment of the biomolecules to an electropolymerized polymer film carrying pendant-reactive groups such as amine or carboxylic group $\left(-\mathrm{NH}_{2},-\mathrm{COOH}\right)$. This latter approach is the most promising, as growth of the polymer film and immobilization of the biomolecules can be performed under different experimental conditions, allowing for the denaturation problem to be overcome. Furthermore, there is minimum physisorption, therefore reducing the likelyhood of leaching of the captured biomolecules [25]. Most importantly, it is critical that covalent immobilization methods maintain the activity of the molecules, increase stability, and ensure accessibility of the analyte to perform biological events such as hybridization of complementary oligonucleotides, antigen-antibody binding, or enzyme-catalyzed reactions [26].

In this paper, we report on the development of an electrochemical immunosensor based on electropolymerized functionalized co-polypyrrole film on which a fragment of an antibody marked by a biomolecule (Hist-tag Single Chain Antibody) is immobilized by the intermediary of a NTA $(\mathrm{N} \alpha, \mathrm{N} \alpha$-Bis(Carboxymethyl)-L-lysine Hydrate) graft coordinated with a metal ion [2728], for the antigen recognition which is an antigenic peptide coupled with BSA (Bovine Serum Albumin). This approach that has never been used until now for antibody immobilization, is interesting because it raises the possibility of reversibly binding the antibody by using a complexing agent of copper without any denaturation of the antibody.

Electrochemical impedance spectroscopy (EIS) has been chosen as the main characterization technique to assess the immunosensor performance, since it is known as an effective tool for the qualitative and quantitative characterization of electrochemical processes occurring in the conducting polymer films [29,30], and is able to probe the interfacial properties of the modified electrode. EIS has also often been used for understanding chemical 
transformations and processes associated with the conductive supports as well as probing antibody-antigen interaction in order to study the immunosensor responses [31-35].

In a first step the EIS technique was applied to study the electrical properties of the copolymer at various dc potentials ranging from 0 to $-1.4 \mathrm{~V} / \mathrm{SCE}$. The contribution of the potential range and then of the electrical and redox properties of the layer was studied to determine the contribution of the conductivity of polypyrrole and of the NTA/copper complex as redox probe in the analytical features of this immunosensor. Next, EIS was applied to monitor the formation of the immunosensor biolayer and of the recognition of a specific antigen by the antibody bonded to the modified copolymer film. Finally, the immunosensor performance was evaluated over a range of potentials according to its sensitivity to the antibody-antigen recognition event.

\section{Materials and methods}

\subsection{Reagents}

Pyrrole monomer (Py) (Sigma) was distilled prior to use. N-hydroxyphtalimide pyrrole (Py-NHP) was synthesized as described previously [28]. Lithium Perchlorate $\left(\mathrm{LiClO}_{4}\right)$, Acetonitrile and $\mathrm{N} \alpha, \mathrm{N} \alpha$-Bis(Carboxymethyl)-L-lysine Hydrate (NTA) were obtained from Fluka. Anhydrous 1,2-Propylene carbonate $\left(\mathrm{C}_{4} \mathrm{H}_{6} \mathrm{O}_{3}\right)$, Acetic Acid $\left(\mathrm{C}_{2} \mathrm{H}_{4} \mathrm{C}_{2}\right)$, Copper (II) Acetate and Sodium Acetate $\left(\mathrm{CH}_{3} \mathrm{COONa} .3 \mathrm{H}_{2} \mathrm{O}\right)$ were purchased from Aldrich. The 6-His tag reduced antibody (Fab fragment hyst-ScAc) and the antigen (peptide conjugated to BSA) were obtained from Wyeth Company.

Copper acetate solution was obtained by diluting $0.2 \mathrm{M}$ copper (II) acetate in acetate buffer solution ( $\mathrm{pH}$ 4.6). The buffer solution used for all experiments was Phosphate Buffer Saline (PBS) containing $137 \mathrm{mM} \mathrm{NaCl}, 2.7 \mathrm{mM} \mathrm{KCl}, 0.01 \mathrm{M} \mathrm{KH}_{2} \mathrm{PO}_{4}$ and $0.01 \mathrm{M} \mathrm{K}_{2} \mathrm{HPO}_{4}, \mathrm{pH}$ 7.4. All solutions were made in ultrapure water (resistance $18.2 \mathrm{M} \Omega \mathrm{cm}^{-1}$ ) produced by a Millipore Milli-Q system.

\subsection{Instrumentation}

\subsubsection{Electrochemical deposition and analysis}


Electrochemical deposition of copolymer and EIS measurements were performed using a Voltalab 80 impedance analyzer. A conventional three electrode cell was used, including a saturated calomel electrode (SCE) as reference electrode, a platinum plate as counter electrode $\left(0.54 \mathrm{~cm}^{2}\right)$ and a modified gold working electrode $\left(0.19 \mathrm{~cm}^{2}\right)$. The impedance spectroscopy measurements were carried out in the frequency range from $0.05 \mathrm{~Hz}$ to $100 \mathrm{kHz}$ at different dc potentials $0,-200,-400,-600,-800$ and $-1400 \mathrm{mV}$ versus SCE electrode, using a modulation voltage of $10 \mathrm{mV}$. Data simulation was made with the commercial software Zview (Scribrerand associates, Charlottesville, VA). All electrochemical measurements were carried out at room temperature in PBS solution at $\mathrm{pH}$ 7.4.

\subsection{Electropolymerization of the PPy/PPy-NHP film on gold electrodes}

Gold electrodes with a defined surface of $0.19 \mathrm{~cm}^{2}$ were provided by the Laboratoire d'Analyse et d'Architecture des Systèmes (LAAS), CNRS Toulouse. The electrodes were made by evaporating a gold layer of $300 \mathrm{~nm}$ thickness on a silicon substrate capped with a $30 \mathrm{~nm}$ titanium adhesion layer. Before electropolymerization, the gold electrode was cleaned in an ultrasonic bath for $10 \mathrm{~min}$ in acetone and dried under a dry nitrogen flow. Subsequently, the electrode was dipped for $2 \mathrm{~min}$ at room temperature in an aqua regia mixture $\left(\mathrm{HCl} / \mathrm{HNO}_{3} / \mathrm{H}_{2} \mathrm{O}\right)$ and then in a basic mixture $\left(\mathrm{H}_{2} \mathrm{O}_{2} / \mathrm{NH}_{4} \mathrm{OH} / \mathrm{H}_{2} \mathrm{O}\right)$ for $5 \mathrm{~min}$ at $80^{\circ} \mathrm{C}, 3: 1: 16$ and 1:1:5 by volume concentration respectively. Between and after these treatments, the gold electrodes were rinsed thoroughly with ultrapure water.

After cleaning, the gold electrodes were immediately placed as working electrode on the three-electrode electrochemical cell. Electropolymerization was performed at 0.9V/SCE for 2 min in a propylene carbonate solution containing $0.04 \mathrm{M}$ pyrrole $(\mathrm{Py}), 0.06 \mathrm{M}$ 3-Nhydroxyphtalimide pyrrole (Py-NHP) and $0.5 \mathrm{M} \mathrm{LiClO}_{4}$ to give the copolymer film $\mathrm{P}(\mathrm{Py}-$ PyNHP). The solution was de-aerated through nitrogen bubbling for $20 \mathrm{~min}$ before use. The

measured charge consumed during the electropolymerization process reached $2.5410^{-3} \mathrm{C}$ corresponding to a charge density of $13.3 \mathrm{mC} \mathrm{cm}^{-2}$. The functionalized polypyrrole film thus obtained is in its electrically p-type conducting state, i.e partially oxidized by the $\mathrm{ClO}_{4}{ }^{-}$anion.

\subsection{Immobilization of the antibody}


After electropolymerization, the copolypyrrole modified electrode was rinsed respectively with propylene carbonate and PBS. Then, it was immersed in $7 \mathrm{mM}$ NTA solution for $1 \mathrm{~h}$ at room temperature to functionalize the copolypyrrole surface with NTA groups via amide links. After thoroughly rinsing with PBS, the electrode was immediately rinsed with sodium acetate/acetic acid buffer solution and immersed in $0.01 \mathrm{M}$ copper (II) acetate solution at $\mathrm{pH} 4.2$ for $15 \mathrm{~min}$ for the coordination of $\mathrm{Cu}^{2+}$ ions with grafted NTA groups. A single Chain Antibody (scab) fragment with a Histidine tag $(0.4 \mathrm{mg} / \mathrm{ml})$ was subsequently immobilized on PPy-NHP/ $\mathrm{NTA} / \mathrm{Cu}^{2+}$ films for $1 \mathrm{~h}$ at room temperature, followed by thorough rinsing with PBS. Fully functionalized electrodes were then incubated at different concentrations of the antigen for 30 min at room temperature.

Figure 1 shows the schematic steps for the formation of the biolayer and the antigenantibody interaction. After the electropolymerization reaction, the electrode surface became covered with polypyrroles bearing activated ester (Py-NHP), which can form covalent bonds with the NTA molecule by reaction with its terminal amine group and the activated ester of the polymer. The new membrane enriched with carboxyl groups stemming from the three terminal carboxyl regions of NTA, was allowed to form a complex with metal ions such as $\mathrm{Cu}^{2+}$. Immediately, these borderline $\mathrm{Cu}$ (II) ions were chelated with the histidine ligand attached to the single-chain antibody fragment by completing coordination with the imidazole ring of the histidine tagged antibody [36].

\section{Results and discussion}

\subsection{Monitoring of the redox process by cyclic voltammetry}

Cyclic voltammetry of the copolymer film $\mathrm{P}(\mathrm{Py}-\mathrm{PyNHP})$ was carried out to determine the potential range where the polypyrrole layer transits from a conducting to an insulating state. Figure 2.1a shows the oxidation wave peaks at $-200 \mathrm{mV}$ where the polymer is strongly conducting, whilst at less than $-800 \mathrm{mV}$ the polypyrrole layer becomes insulating.

After the immobilization of NTA and copper interaction the cyclic voltammetry (figure 2.1b) shows at very negative potential a broken reduction wave of copper corresponding to the 
reduction of $\mathrm{Cu}^{2+} / \mathrm{Cu}^{0}$ and followed by two oxidation waves observed at $200 \mathrm{mV}$ and $500 \mathrm{mV}$ corresponding to the oxidation state of $\mathrm{Cu} / \mathrm{Cu}^{+}$and $\mathrm{Cu}^{+} / \mathrm{Cu}^{2+}$. The differential pulse voltammetry was investigated to avoid capacitive current and in order to determine the potential peak of the reduction waves of copper. Figure 2.2 shows the DPV waves in reduction state of the copolymer after NTA/copper immobilization. Besides the reduction processes of the polypyrrole layer a reduction wave between $-1.4 \mathrm{~V}$ to $-1.1 \mathrm{~V}$ is observed corresponding to the reduction of $\mathrm{Cu}^{2+}$ to $\mathrm{Cu}^{0}$.

\subsection{Copolymer behavior at various dc potentials}

The Nyquist impedance plots of the copolymer films at different applied dc potentials are presented in Fig. 3, where $\operatorname{Re}(z)$ is the real part and $\operatorname{Im}(z)$ is the imaginary part of the complex impedance $Z$. The obtained plots were analyzed by using several models of equivalent circuits which are appropriate for a conducting polymer film as described in the literature [29,37-39], but the fittings were unsatisfactory (poor $\chi^{2}$ correlation coefficients). In contrast, we obtained good fittings for frequencies ranging from 0.05 to $100000 \mathrm{~Hz}\left(\chi^{2} \approx 10^{-3}\right)$ using the equivalent circuit depicted in Fig.4, where the various parameters are represented as: Rs solution resistance, $\mathrm{C}_{\mathrm{f}}$ capacitance of the copolymer film, $\mathrm{R}_{\mathrm{f}}$ polymer film resistance, CPE constant phase element, $\mathrm{R}_{\mathrm{i}}$ resistance of ionic transfer and W Warburg Impedance. All of the values of the electrical parameters are presented in table 1(first line). In fact, this circuit allowed distinguishing between the intrinsic electrical characteristics related to the copolymer film in $C_{f}$ and $R_{f}$ which is related to the mobility of ionic charge into the polymer backbone during the doping dedoping process and the $R_{c t}$ charge transfer resistance at the polymer|electrolyte interface or charge transfer resistance at the Pt|polymer interface, according to [29].

Je garderais Rct au lieu de Ri sur le schema 4.

The impedance spectra were measured at dc potentials ranging between -1.4 and $0 \mathrm{~V}$, covering the range in which the polymer film transits from insulating to conducting states [40, 41]. Nonetheless, the spectra show considerable changes with potential throughout the entire frequency range due to the transformations occurring in the film during its insulator-conductor transition. 
Figures 5 and 6 show the variation with applied dc potential of capacitance $\left(\mathrm{C}_{\mathrm{f}}\right)$ and resistance $\left(R_{f}\right)$ respectively, of the polymer film as deduced from fitting the high frequency impedance data to the equivalent circuit shown in Fig. 4. At large negative potentials between $800 \mathrm{mV}$ and $-1400 \mathrm{mV}$ the purely resistive behavior of the film is observed (see Figures 5, 6) and no ionic transfer occurs, with the capacitance remaining low at about $3.5 \mu \mathrm{F} \mathrm{cm}^{2}$. At less negative potential $(-200 \mathrm{mV})$ the polymer film undergoes a transition from the undoped state to the doped state, which is accompanied by the ionic exchange of ions from solution to a polymer layer to assure the doping process. The capacitance of the film in this case increases to around $1.7 \mathrm{mF} \mathrm{cm}^{2}$. As expected, the film resistance also drops as the film becomes conductive.

The expression of the capacitance of the polypyrrole film as follows:

$$
C_{f}=\frac{\varepsilon_{0} \varepsilon A}{d}
$$

Where the $\varepsilon_{0}$ the vacuum dielectric constant and the $\varepsilon$ is the double layer dielectric constant, $\mathrm{A}$ is the surface area and $\mathrm{d}$ the thickness of the film.

The increase of the capacitance of the film will be dominated by the increase in negative charge originating from the phosphate anions, i.e. the increasing of $\mathrm{C}_{\mathrm{f}}$ with the potential is related to the doping level of the film, as already observed in [29, 42]. The doping process of the polypyrrole layer also leads to a slight increase of the thickness of the film by the swelling of the polymer layer due to incorporation of the counter ions, however, this will have a negligible effect on the change in the polymer capacitance.

\subsection{Electrical characterization of the biofilm at various dc potentials by impedance spectroscopy}

Figure 7 shows Nyquist plots, for the assembly of the biofilm on gold electrode for various applied potentials. All the electrical parameters values, calculated frim fitting the impedance datye to the equivalent circuit shown in Fig. 4, are presented in Table 1.

After the immobilization of $\mathrm{NTA} / \mathrm{Cu}^{2+}$ complex, the charge transfer resistance $\mathrm{R}_{\mathrm{ct}}$ is due to the redox process of the copper. Then, the resistance variation indicate that the attachment of 
$\mathrm{NTA} / \mathrm{Cu}^{2+}$ complex facilitates charge transfer through the modified electrode, at potentials -800 $\mathrm{mV}$ and $-1400 \mathrm{mV}$. Finally, the subsequent immobilization of scAb on the electrode was indicated by an increase of $\mathrm{R}_{\mathrm{ct}}$.

The impedance spectra for the different layers at the potentials from 0 to $-0.8 \mathrm{~V}$ indicate a diffusion behavior, when Warburg impedance is higher than $\mathrm{R}_{\mathrm{ct}}$. This can be explained by the diffusion of ions into the polypyrrole layer to assure the electroneutrality in the dedoping process. Concerning the electrochemical behavior of the layer at $-1400 \mathrm{mV}$, a low Warburg impedance was obtained which is attributed to the decrease in ionic movement from the filmelectrolyte interface as the polypyrrole layer is in insulating state and no ionic exchange was obtained at this potential.

At $-1400 \mathrm{mV}$ a low charge transfer resistance is obtained for the $\mathrm{P}(\mathrm{Py}-$ PyNHP) $/ \mathrm{NTA} / \mathrm{Cu}^{2+} /$ His-Tag film where $\mathrm{R}_{\mathrm{ct}}=272.6 \Omega \mathrm{cm}^{2}$ compared to the value of $\mathrm{R}_{\mathrm{ct}}=9943$ $\Omega \mathrm{cm}^{2}$ obtained at $0 \mathrm{~V}$. At $-1400 \mathrm{mV}$ the reduction of the $\mathrm{NTA} / \mathrm{Cu}^{2+} / \mathrm{His}-\mathrm{Tag}-\mathrm{Ab}$ complex results in an increase of Faradaic current. In comparison, it is known that NTA/ $\mathrm{Co}^{2+}$ complex undergoes the reduction process $\mathrm{Co}^{2+} / \mathrm{Co}$ at low potential range as already demonstrated in the case of polypyrrole functionalized with $\mathrm{NTA} / \mathrm{Co}^{2+}[27]$ and monolayers of $\mathrm{NTA} / \mathrm{Co}^{2+}$ deposited on glassy carbon electrode [43] where the reduction potential is observed around $-1.2 \mathrm{~V}$. Consequently, this redox process leads to a decrease of the charge transfer resistance of the immunosensor membrane at this low potential.

\subsection{Antigen detection using EIS}

Systematically, the electrode modified with histidine-tagged Antibody fragment was equilibrated with a range of concentrations of the specific antigen (from 0 to $100 \mathrm{ng} \mathrm{mL}^{-1}$ ). The Bode impedance diagrams at $0 \mathrm{~V},-800 \mathrm{mV}$ and $-1400 \mathrm{mV}$ and Nyquist plot at $-1400 \mathrm{mV}$ obtained after incubation with different concentrations of antigen, are shown in Fig. 8 and Fig. 9. The obtained spectra clearly show that the impedance increases with the increase of the antigen concentration, which indicates that the antigen was linked to the specific sites of the antibody immobilized on $\mathrm{P}(\mathrm{Py}-\mathrm{PyNHP}) / \mathrm{NTA} / \mathrm{Cu}^{2+}$ film and disturbing the electrical properties of the layer. Furthermore, as previously for the dc potentials from 0 to $-800 \mathrm{mV} / \mathrm{SCE}$ the impedance 
spectra of antigen-antibody $(\mathrm{Ag}-\mathrm{Ab})$ interactions indicate a diffusion behavior, where as the impedance spectra obtained at $-1400 \mathrm{mV}$ show that the biolayer presents an electroactivity rather high by comparison to its behavior at the other potentials due to the reduction of copper ions in the NTA complex.

The electrical parameters obtained from the fitted data are summarized in table 2. From these results, the Rct parameter appears as the important value in the case of antibody -antigen interaction. Variation of $\mathrm{R}_{\mathrm{f}}$ and $\mathrm{C}_{\mathrm{f}}$ parameters corresponding to the electrical characteristics of the polyprrole layer are also observed specially at $0 \mathrm{~V}$ where the polypyrrole is in its conducting state. However these variations are low compared to those obtained for Rct corresponding to the charge transfer occurring in the biolayer. The increasing of electronic conduction at $-1400 \mathrm{mV}$ caused by reduction of copper ion in the complex exhibits a much higher $\mathrm{R}_{\mathrm{ct}}$ variation than for the other dc potentials.

In order to study the immunosensor response, at various dc potentials, the calibration curves corresponding to the variation of the charge transfer resistance $R_{c t}$ versus specific antigen concentrations in PBS solution, from the fitted data (Table 2), is presented in Fig.10. The immunosensor calibration curve exhibits a linear relation between $R_{c t}$ and the antigen concentration followed by a saturation process. The dynamic range of detection varies, depending on the applied dc potential during the measurements. The sensitivity, detection limit calculated from the slope of the calibration curve in the linear part and the correlation coefficient of the linear regression of these plots are summarized in Table 3. The sensitivity, detection limit and dynamic range of the immunosensor varies according the dc potential of impedance measurement.

The sensitivity and dynamic range obtained at applied dc potential of 0 and $-200 \mathrm{mV}$, where the polypyrrole layer is still in conducting state were of same order of magnitude: $310^{5}$ $\Omega \mathrm{cm}^{2} / \mu \mathrm{g} \mathrm{mL}^{-1}$, in concentration of antigen ranging from 0.1 to $0.5 \mathrm{ng} \mathrm{mL}{ }^{-1}$, the detection limit corresponding to the lower concentration value measured is $40 \mathrm{pg} \mathrm{mL}^{-1}$. In the case of the measurements obtained in dc potential range from $-400 \mathrm{mV}$ to $-800 \mathrm{mV}$ where the polypyrrole layer is in the insulating state, the dynamic range is very low and saturation is obtained at $0.1 \mathrm{ng}$ $\mathrm{mL}^{-1}$. Whereas, for measurement carried out at $-1400 \mathrm{mV}$ the sensitivity of the immunosensor 


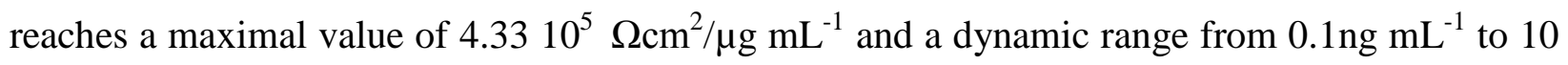
$\mathrm{mg} \mathrm{mL} \mathrm{m}^{-1}$ was obtained; the detection limit corresponding to the lower concentration value measured is $21.4 \mathrm{pg} \mathrm{mL}^{-1}$. Also a good reproducibility was obtained for the immunosensor working at $-1400 \mathrm{mV}$ : $9 \%$ standard deviation on measurements performed with four different immunosensors.

\section{Conclusion}

In this study, we have introduced a new method for the fabrication of an immunosensor based on immobilization of His-tag antibody to an electropolymerized copolypyrrole film bearing a NTA/copper complex. Firstly, we have demonstrated that by using electrochemical impedance spectroscopy combined with theoretical equivalent circuits, it is possible to determine the electrical properties and to model the behavior of the copolymer film according to dc applied potential. We have also shown that EIS can be used to monitor the engineering of the biolayer.

We demonstrate that, depending on the dc potential, the electrical behavior of the biolayer is modified depending on the redox activity process occuring. At a potential range from of 0 to $400 \mathrm{mV}$ where the polypyrrole layer is in a conducting state, diffusion behavior is observed corresponding to the exchange of ions from electrolyte to the layer. At a highly negative potential of $-1400 \mathrm{mV}$, the polypyrrole layer is electrically insulating and at this potential the reduction of the NTA/copper complex takes place, leading to a small increase in electronic conductivity and correspondingly low charge transfer resistance of the biolayer. The detection of the specific antigen was monitored by EIS by varying the dc potential to determine the potential where the sensor is more sensitive. Results show that at a dc potential of $-1400 \mathrm{mV}$ where the redox process of the complex in the biolayer $\left(\mathrm{NTA} / \mathrm{Cu}^{2+} / \mathrm{his}-\mathrm{Tag}\right)$ occurs leads to sensitive modification of the charge transfer resistance and the immunosensor operates over a larger dynamic range compared to those obtained at less negative potentials.

\section{Acknowledgements}

This work was supported by European Commission through DVT-IMP project (FP6-IST-34256) and by NATO through CLG grant \# CLG 982802. 


\section{References}

[1] I. S. Park, N. Kim, Development of a chemiluminescent immunosensor for chloramphenicol, Analytica Chimica Acta, 578 (2006) 19-24.

[2] J. Ramón-Azcón, E. Valera, Á. Rodríguez, A. Barranco, B. Alfaro, F. Sanchez-Baeza, M.P. Marco, An impedimetric immunosensor based on interdigitated microelectrodes (ID $\pm \mathrm{mE}$ ) for the determination of atrazine residues, Biosensors and Bioelectronics, 23 (2008) 1367- 1373.

[3] I. M. Ciumasu, P. M. Krämer, C.M. Weber, G.Kolb, D. Tiemann, S. Windisch, I.S. Frese, A.A. Kettrup, A new, versatile field immunosensor for environmental pollutants, Biosensors and Bioelectronics, 21 ( 2005) 354- 364.

[4] B. D. Malhotra, A. Chaubey, S.P. Singh, Prospects of conducting polymers in biosensors, Analytica Chimica Acta, 578 (2006) 59-74.

[5] J. Travas-Sejdic, H. Peng, R.P. Cooney, G.A. Bowmaker, M.B. Cannell, C. Soeller, Amplification of a conducting polymer-based DNA sensor signal by CdS nanoparticles, Current Applied Physics, 6 (2006) 562- 566.

[6] P. N. Bartlett, P. R. Birkin, The application of conducting polymers in biosensors, Synthetic Metals, 61 (1993) 15-21.

[7] M. Omastová, I. Chodák , J. Pionteck, Electrical and mechanical properties of conducting polymer composites, Synthetic Metals, 102 (1999) 1251-1252.

[8] T. Sugano and M. Kinoshita, Magnetic properties of conducting polymers: Sulfur-linked aromatic hydrocarbons with and without acceptor doping, Synthetic Metals, 17 (1987) 685-690.

[9] H. Stubb, E. Punkka , J. Paloheimo, Electronic and optical properties of conducting polymer thin films, Materials Science Reports 10 (1993) 85-140.

[10] R.C. Patil, S. Radhakrishnan, Conducting polymer based hybrid nano-composites for enhanced corrosion protective coatings, Progress in Organic Coatings, 57 (2006) 332-336.

[11] K. Gurunathan, D. P. Amalnerkar D. C. Trivedi, Synthesis and characterization of conducting polymer composite $\left(\mathrm{PAn} / \mathrm{TiO}_{2}\right)$ for cathode material in rechargeable battery, Materials Letters 57 (2003) 1642-1648.

[12] D. Chinn, M. DeLong, A. Fujii, S. Frolov, K. Yoshino, Z.V. Vardeny, Synthesis and processing of conducting polymer microlasers and microsize light emitting diodes, Synthetic Metals 102 (1999) 930-932.

[13] E. Sahin, E.Sahmetlioglu, I. M. Akhmedov, C.Tanyeli, L.Toppare, Synthesis and characterization of a new soluble conducting polymer and its electrochromic devices, Organic Electronics 7 (2006) 351- 362.

[14] A. Azioune, F. Siroti, J. Tanguy, M. Jouini, M. M. Chehimi, B. Miksa, S. Slomkowski, Interactions and conformational changes of human serum albumin at the surface of electrochemically synthesized thin polypyrrole films, Electrochimica Acta 50 (2005) 1661-1667. 
[15] B. Saoudi, Ch. Despas, M. M. Chehimi, N. Jammul, M. Delamar, J. Bessière, A. Walcarius, Study of DNA adsorption on polypyrrole: interest of dielectric monitoring, Sensors and Actuators B-chemical 62 (2000) 35-42.

[16] A. Ramanavicius, A. Ramanaviciene, A. Malinauskas, Electrochemical sensors based on conducting polymer-polypyrrole, Electrochimica Acta 51 (2006) 6025-6037.

[17] A. Ramanaviciene, A. Kausaite, S.Tautkus and A. Ramanavicius, Biocompatibility of polypyrrole particles: an in vivo study in mice, Journal of Pharmacy and Pharmacology 59 (2007) 311- 315.

[18] A. Sargent, O. A. Sadic, Monitoring antibody-antigen reactions at conducting polymer-based immunosensors using impedance spectroscopy, Electrochemica Acta 44 (1999) 4667-4675.

[19] M. Ogasawara, K. Funahashi, T. Demura, T. Hagiwara, K. Iwata, Enhancement of electrical conductivity of polypyrrole by stretching, Synthetic Metals 14 (1986) 61-69.

[20] K.K. Kanazawa, A.F. Diaz, M.T. Krounbi, G.B. Street, Electrical properties of pyrrole and its copolymers, Synthetic Metals 4 (1981) 119-130.

[21] A. Ramanavicius, K. Habermüller, E. Csöregi, V. Laurinavičius , W. Schuhmann, Polypyrrole entrapped quinohemoprotein alcohol dehydrogenase. evidence for direct electron transfer via conducting polymer chains, Analytical Chemistry 71 (1999) 3581-3586.

[22] M. Gerard, A. Chaubey and B.D. Malhotra, Application Of Conducting Polymers To Biosensors, Biosensors Bioelectronics 17 (2002) 345-359.

[23] W. Khan, M. Kapoor and N. Kumar, Covalent attachment of proteins to functionalized polypyrrole-coated metallic surfaces for improved biocompatibility, Acta Biomaterialia 3 (2007) 541- 549.

[24] U. Lange, N. V. Roznyatovskaya, V. M. Mirsky, Conducting polymers in chemical sensors and arrays, Analytica Chimica Acta 614 (2008) 1-26.

[25] O. Ouerghi, A. Senillou, N. Jaffrezic-Renault, C. Martelet, H. Ben Ouada, S. Cosnier, Gold electrode functionalized by electropolymerization of a cyano $\mathrm{N}$-substituted pyrrole: application to an impedimetric immunosensor, Journal of Electroanalytical Chemistry 501(2001) 62-69.

[26] N. K. Guimarda, N. Gomezb Ch. E. Schmidt, Conducting polymers in biomedical engineering, Progress in Polymer Science 32 (2007) 876-921.

[27] N. Haddour, S. Cosnier, Ch.Gondran, Electrogeneration of a Poly(pyrrole)-NTA Chelator Film for a Reversible Oriented Immobilization of Histidine-Tagged Proteins, Journal of American Chemical Society 127 (2005) 5752- 5753.

[28] S. Chebil, I. Hafaid , H. Sauriat-Dorizon , N. Jaffrezic-Renault, A. Errachid , V.Auger, Z. Ali, H. KorriYoussoufi, Electrochemical real-Time detection of model in plasma based on functionalized polypyrrolesNTA conjugate to His-tag scAntibody , Adv. Mater.(submitted).

[29] A.Hallik, A. Alumaa, J. Tamm, V.Sammelselg, M. Vaartnou, A. Janes, E. Lust, Analysis of electrochemical impedance of polypyrrole|sulfate and polypyrrole|perchlorate films, Synthetic Metals 156 (2006) 488- 494. 
[30] C. Ehrenbeck, K. Jüttner, S. Ludwig , G. Paasch, The electrochemical impedance of a free-standing polypyrrole membrane,Electrochimica Acta 43 (1998) 2781-2789.

[31] D.D. Macdonald, Reflections on the history of electrochemical impedance spectroscopy, Electrochimica Acta 51 (2006) 1376-1388.

[32] M. Wang, L. Wang, G. Wang , X. Ji , Y. Bai , T. Li , S. Gong, J. Li , Application of impedance spectroscopy for monitoring colloid Au-enhanced antibody immobilization and antibody-antigen reactions, Biosensors and Bioelectronics 19 (2004) 575-582.

[33] R. Pei, Z. Cheng, E. Wang, X. Yang, Amplification of antigen-antibody interactions based on biotin labeled protein-streptavidin network complex using impedance spectroscopy, Biosensors and Bioelectronics 16 (2001) 355-361.

[34] S. Helali, A. Abdelghani, I. Hafaiedh, C. Martelet, M.I. Prodromidis, T. Albanis and N. Jaffrezic-Renault, Functionalization of niobium electrodes for the construction of impedimetric biosensors ,Materials Science and Engineering C 28 ( 2008) 826-830.

[35] I. Hafaiedh, S. Helali, K. Cherif, A. Abdelghani and G. Tournier, Characterization of tin dioxide film for chemical vapors sensor, Materials Science and Engineering C 28 (2008) 584- 587.

[36] G. Bayramoglu. A. Ulku Senel, M. Yakup Arica, Effect of spacer-arm and Cu(II) ions on performance of 1histidine immobilized on poly(GMA/MMA) beads as an affinity ligand for separation and purification of IgG, Separation and Purification Technology 50 (2006) 229- 239.

[37] A. A. Diagne, M. Fall, M. Guene, M. M. Dieng, F. Deflorian, S. Rossi, P. Bonora, C. Della Volpe, Electrochemical impedance spectroscopy of polybithiophene films in an aqueous $\mathrm{LiClO}_{4}$ solution,Comptes rendus Chimie 10 (2007) 558- 563.

[38] S. A. Sezai, S. Sibel, A. Murat, T. C. Metehan, Electrochemical impedance spectroscopy and morphological analyses of pyrrole, phenylpyrrole and methoxyphenylpyrrole on carbon fiber microelectrodes,Surface and Coatings Technology 202 (2008) 3997-4005.

[39] N.F. Atta, A. Glal, F. Khalifa, Electrodeposited metals at conducting polymer electrodes: I-Effect of particle size and film thickness on electrochemical response, Applied surface Science 253 (2007) 42734282.

[40] A.F. Diaz, I.C Catillo, J.A. Logan, L. Wen-Young, Electrochemistry of conducting polypyrrole films, Journal of Electroanalytical Chemistry 129 (1981) 115- 132.

[41] T. Shimidzu, A. Ohtani, T. Iyoda, K. Honda,Charge-controllable polypyrrole/polyelectrolyte composite membranes : Part II. Effect of incorporated anion size on the electrochemical oxidation-reduction process, Journal of Electroanalytical Chemistry 224 (1987) 123-135.

[42] J. Heinze, R. Bilger, Ion movements during redox switching of polypyrrole. Experiment and simulation, Berichte Der Bunsen-Gesellschaft-Physical Chemistry Chemical Physics 97 (1993) 502- 506.

[43] R. Blankespoor, B. Limoges, B. Schollhorm, J- L. Syssa-Magalé, D.Yazidi, Dense monolayers of metal-chelating ligands covalently attached to carbon electrodes electrochemically and their 
useful applications in affinity binding of histidine-tagged proteins, Langmuir. 21(2005) 33623375 . 


\section{Figure captions}

Fig.1. Schematic representation of the fabrication process of the multilayer system of the immunosensor on the gold electrode.

Fig. 2.1. Cyclic voltammetry of copolypyrrole film analysed in PBS pH 7.0. after polymerization reaction, with scan rate of $50 \mathrm{mV} / \mathrm{s}$ (a) $\mathrm{P}(\mathrm{Py}-\mathrm{PyNHP})$, (b) $\mathrm{P}(\mathrm{Py}-\mathrm{PyNHP}) / \mathrm{NTA}-\mathrm{Cu}^{2+}$

Fig. 2.2. DPV waves in reduction state of Py-PyNTA-Cu ${ }^{2+}$

Fig. 3 Nyquist plot obtained for copolymer film electrodeposited on the gold electrode, at different formal dc potentials vs. SCE in 0.01 mM PBS solutions $\mathrm{pH}$ 7.4. The dc potentials used are: $0,-200,-400,-600,-800$ and $-1400 \mathrm{mV}$. The spectra were obtained between $0.05 \mathrm{~Hz}-100 \mathrm{KHz}$. Amplitude of alternative voltages: $10 \mathrm{mV}$.

Fig.4 Equivalent electrical circuit model for complex impedance plot.

Fig.5 Dependence of the polymer film resistance $R_{f}$, with dc potential, obtained from fit of equivalent circuit parameters to experimental data.

Fig.6 Dependence of the polymer film capacitance with dc potential, obtained from fit of equivalent circuit parameters to experimental data.

Fig. 7 Nyquist plot (-Im(z) vs. $\operatorname{Re}(\mathrm{z})$ ) for the faradic impedance measurements at (a) $0 \mathrm{mV}$, (b)$800 \mathrm{mV}$ and (c)-1400 mV) vs. SCE, in $0.01 \mathrm{mM}$ PBS pH 7.4 solution, corresponding to the different layers grafted onto the gold electrode : $\mathrm{P}(\mathrm{Py}-\mathrm{PyNHP}), \mathrm{P}(\mathrm{Py}-\mathrm{PyNHP}) / \mathrm{NTA}-$ $\mathrm{Cu}^{2+}$ and P(Py-PPyNHP)/NTA-Cu${ }^{2+} / \mathrm{Ab}$. Spectra were obtained between $0.05 \mathrm{~Hz}-100$ KHz. Amplitude of Alternative voltage $: 10 \mathrm{mV}$.

Fig. 8 Bode diagrams (|Z (f)| vs.log (f) at $0 \mathrm{mV}$, (b)-800 mV and (c)-1400 mV vs.SCE, in PBS solution $\mathrm{pH} 7.4$, obtained for the faradic impedance measurement on modified gold electrode with histidine tagged reduced Antibody under various concentrations of 
antigen. Spectra were obtained between $0.05 \mathrm{~Hz}-100 \mathrm{KHz}$. Amplitude of alternative voltage: $10 \mathrm{mV}$.

Fig.9 Nyquist plots (-Im(z) vs. $\operatorname{Re}(\mathrm{z})$ ) at $-1400 \mathrm{mV}$ vs.SCE in PBS solution pH 7.4, obtained for the faradic impedance measurement on modified gold electrode with histidine tagged reduced Antibody under various concentrations of antigen. Spectra were obtained between $0.05 \mathrm{~Hz}-100 \mathrm{kHz}$. Amplitude of alternative voltage: $10 \mathrm{mV}$.

Fig.10 Calibration curves describing the variation of charge transfer resistance $R_{\mathrm{ct}}$ against antigen concentration for various potential $(0,-200,-400,-600,-800,-1400 \mathrm{mV})$.

Fig.11 Calibration curves describing the variation of charge transfer resistance $R_{c t}$ against antigen concentration for potential $-1400 \mathrm{mV}$.

\section{Table captions}

Table 1 Electrochemical parameters obtained from fitting of the experimental results of $\mathrm{P}(\mathrm{Py} / \mathrm{Py}-$ NHP) layer at different potentials $(0,-200,-400,-600,-800,-1400 \mathrm{mV})$.

Table 2 Electrochemical parameters obtained from fitting of the experimental results of antigen detection at different potentials $(0,-200,-400,-600,-800,-1400 \mathrm{mV})$.

Table 3 Sensitivity, detection limit, correlation coefficient and the dynamic range of immunosensor responses at various dc potentials. 

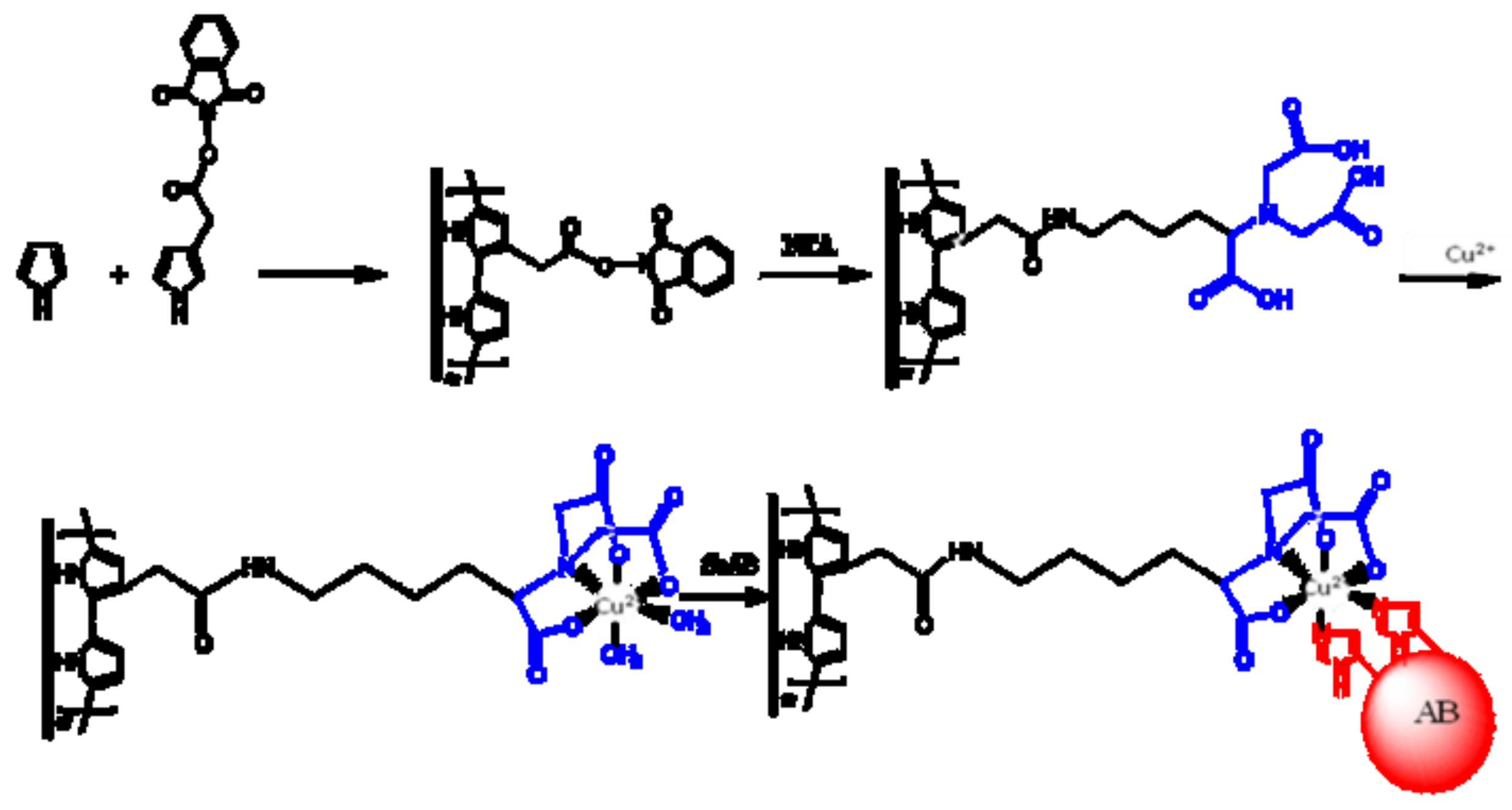


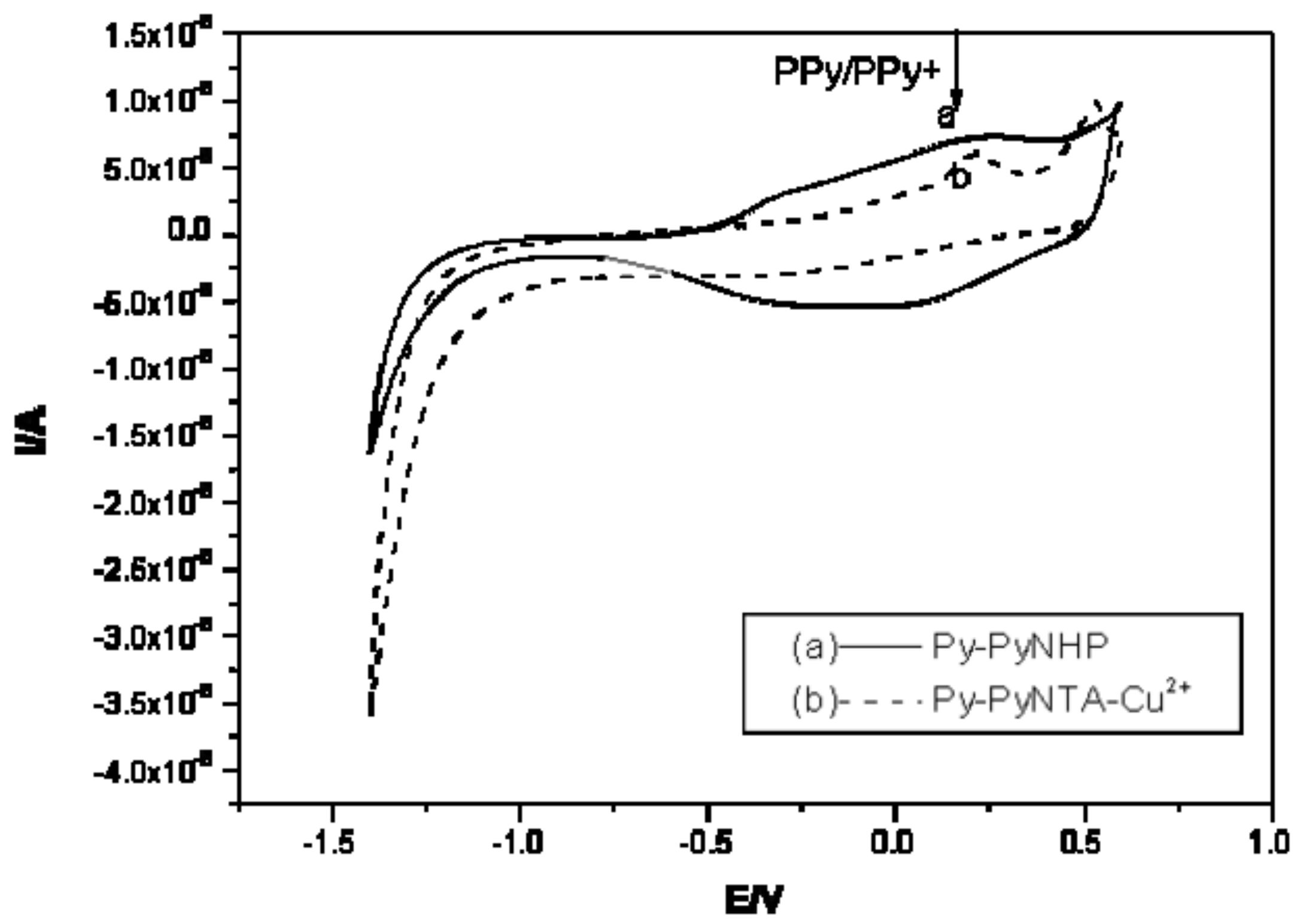




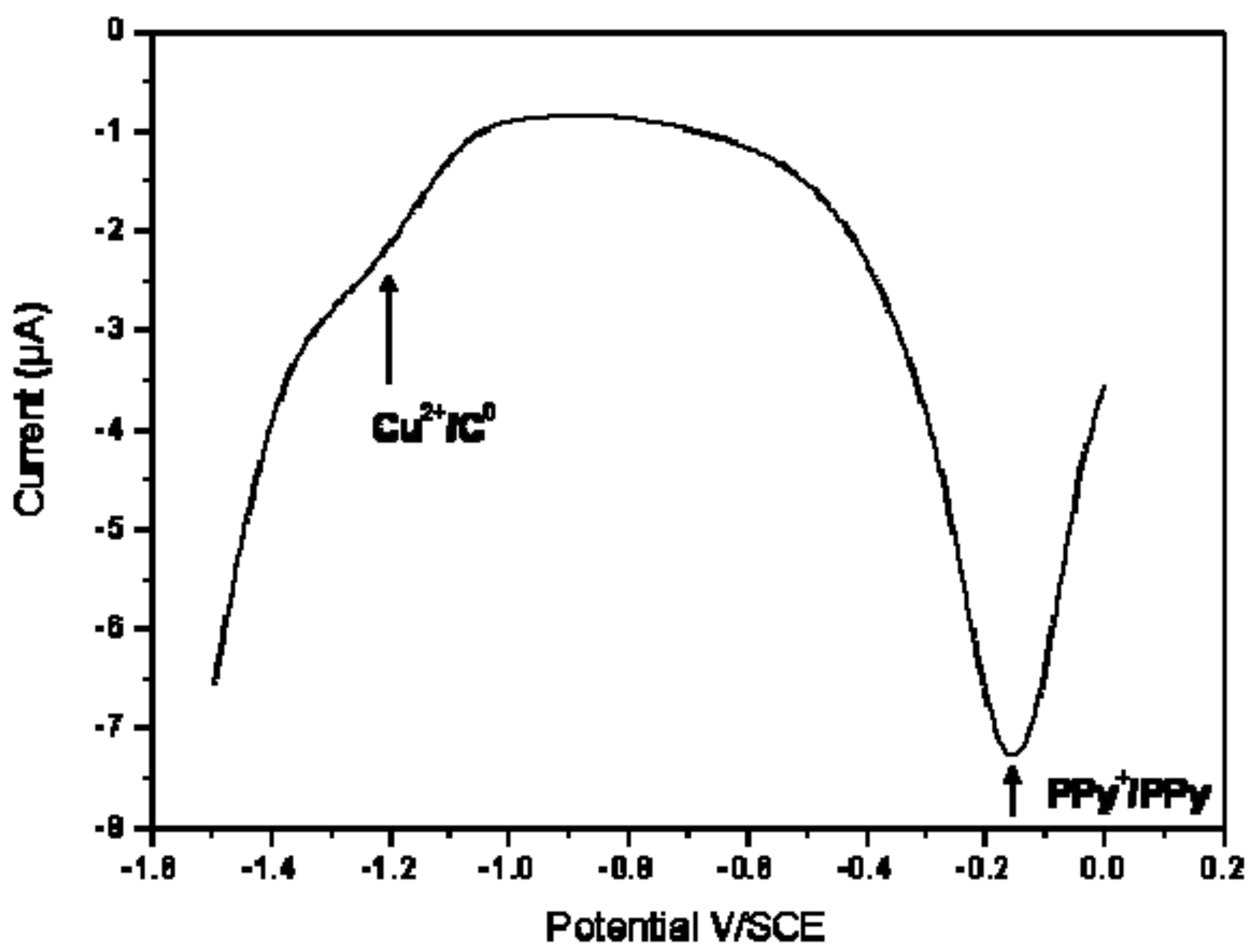




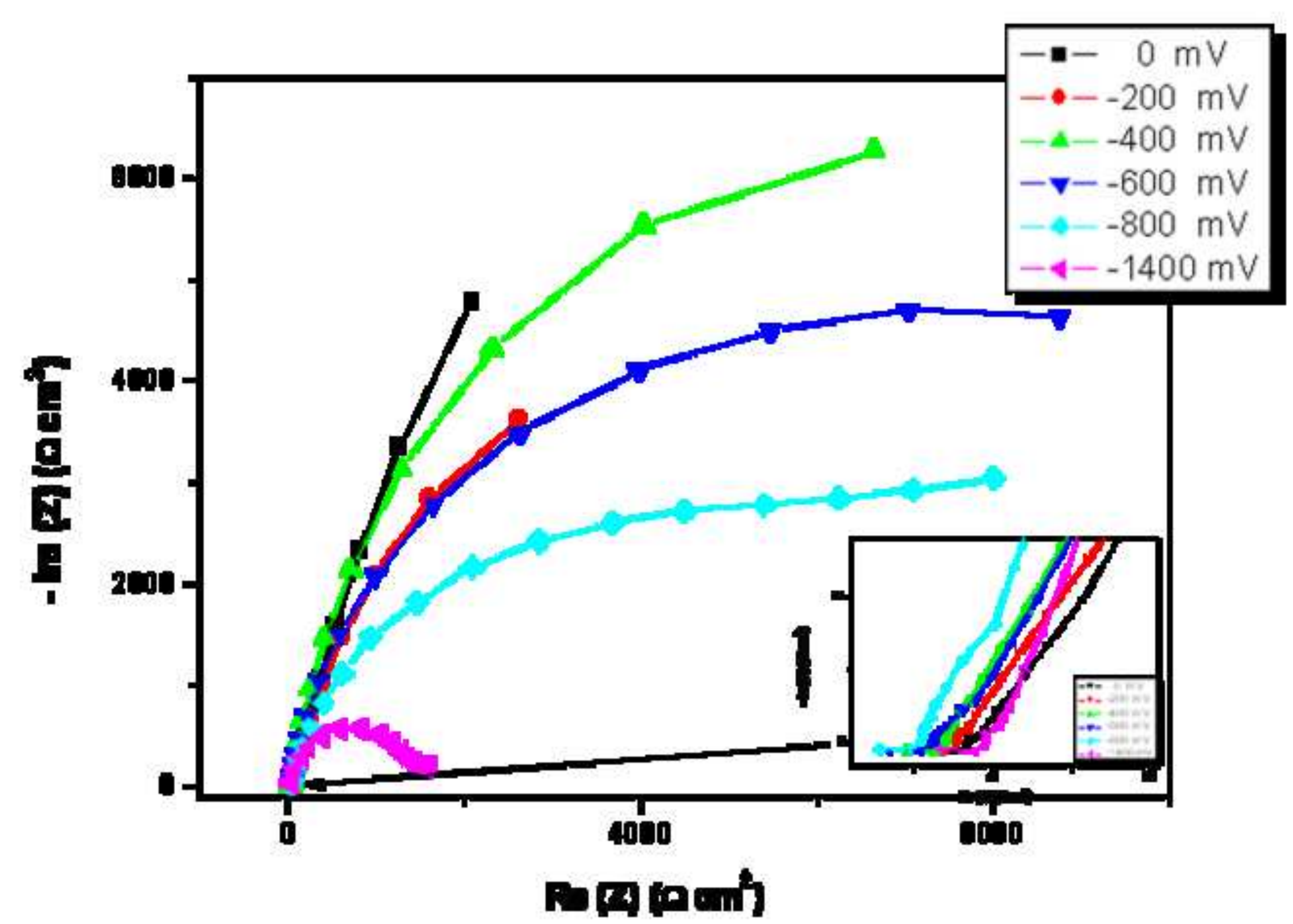

Click here to download high resolution image 
Click here to download high resolution image

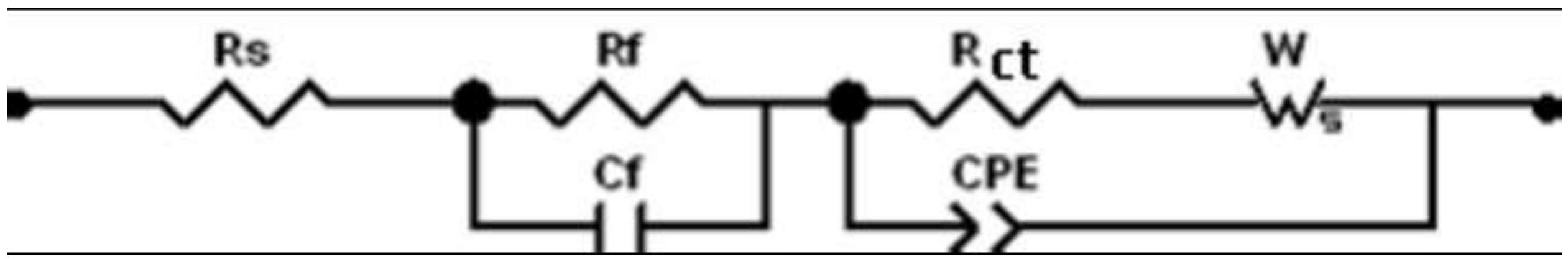




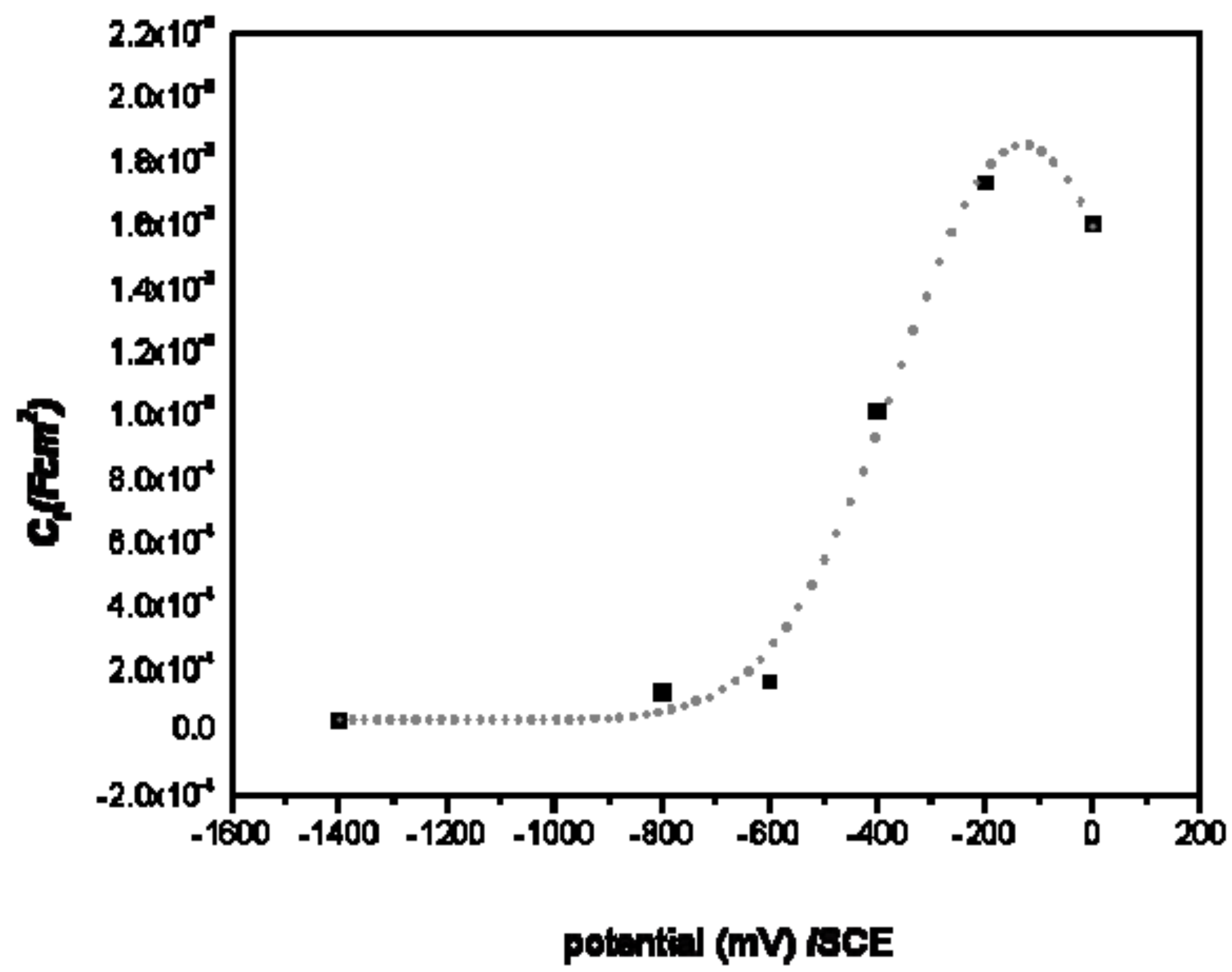




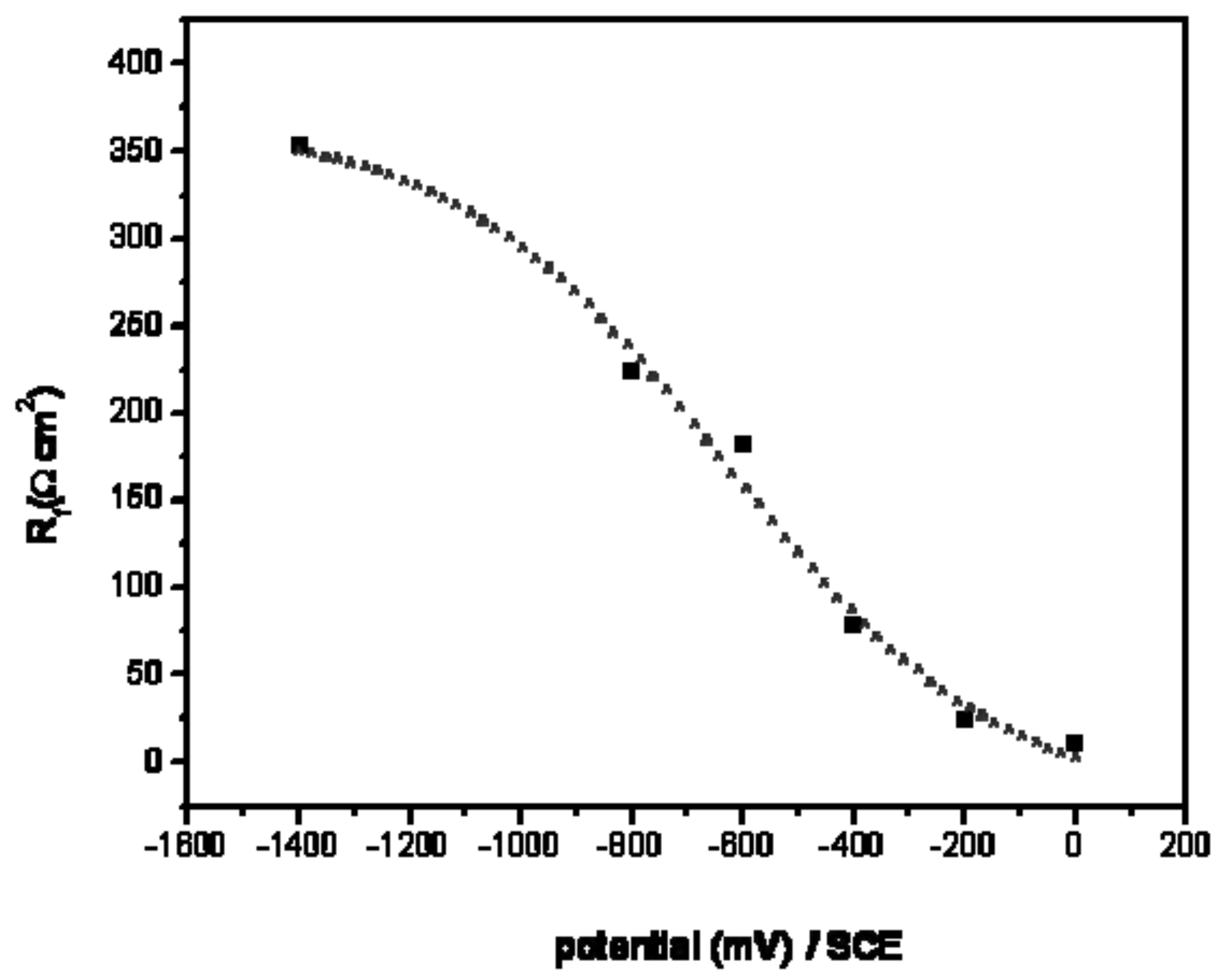




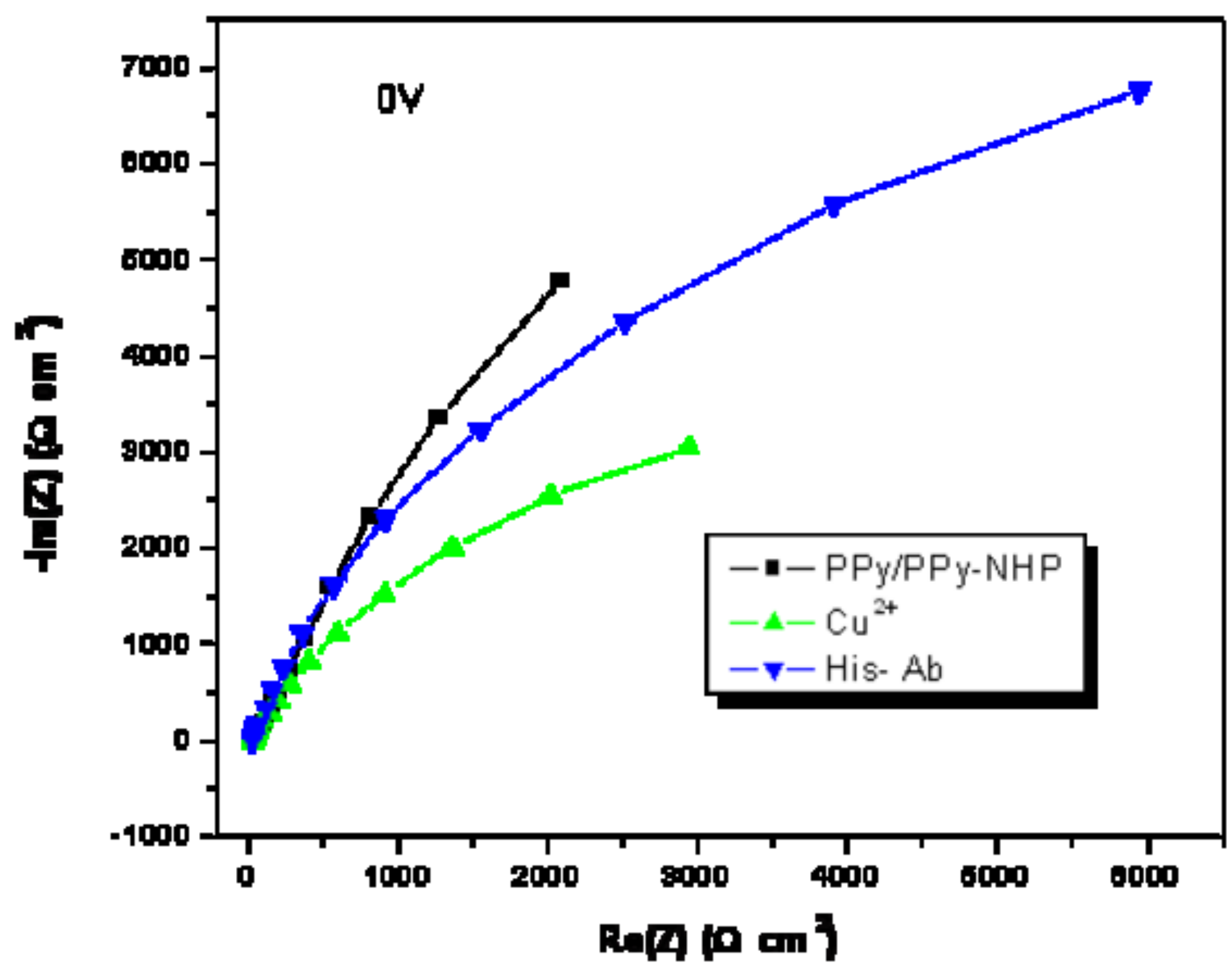




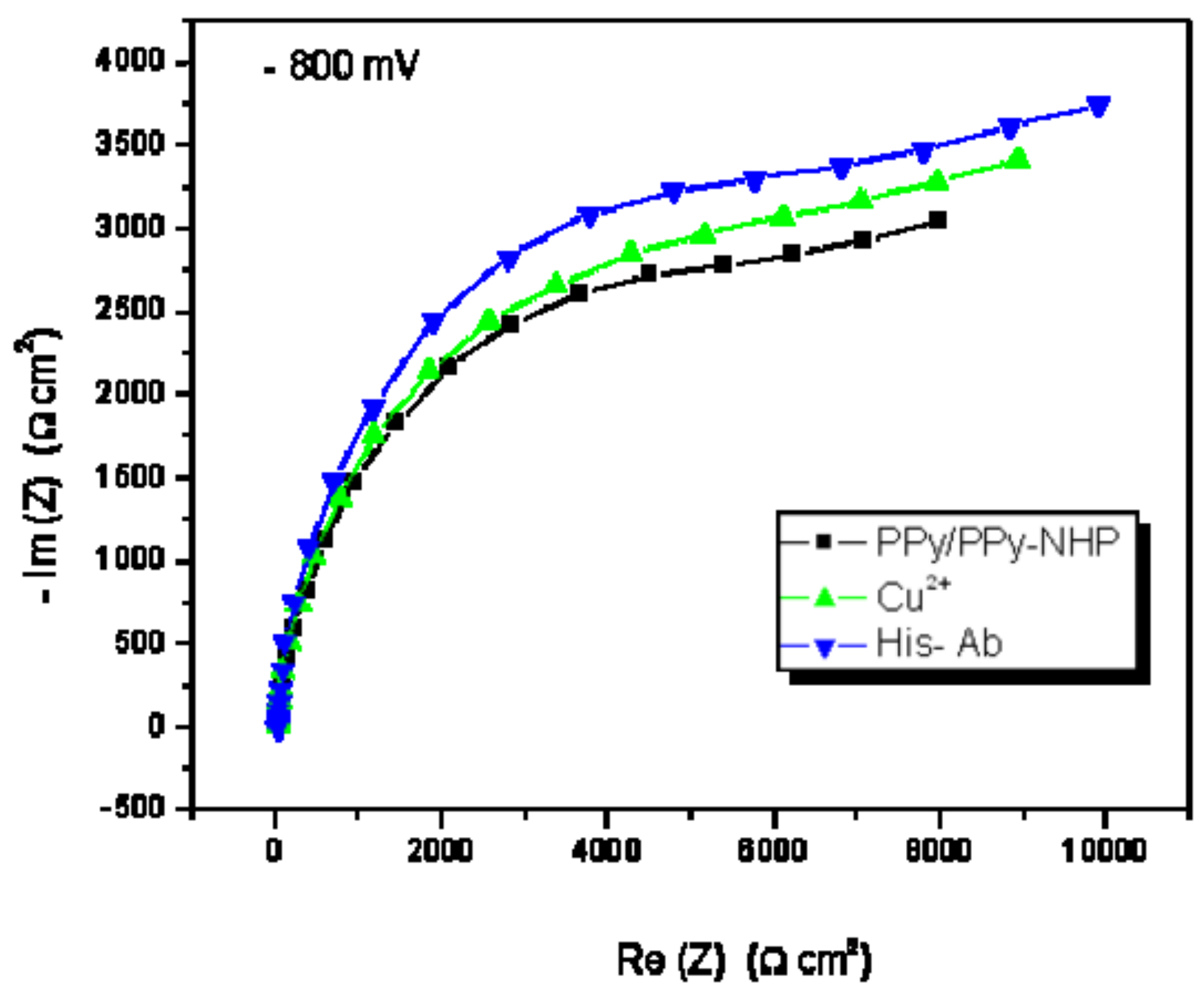




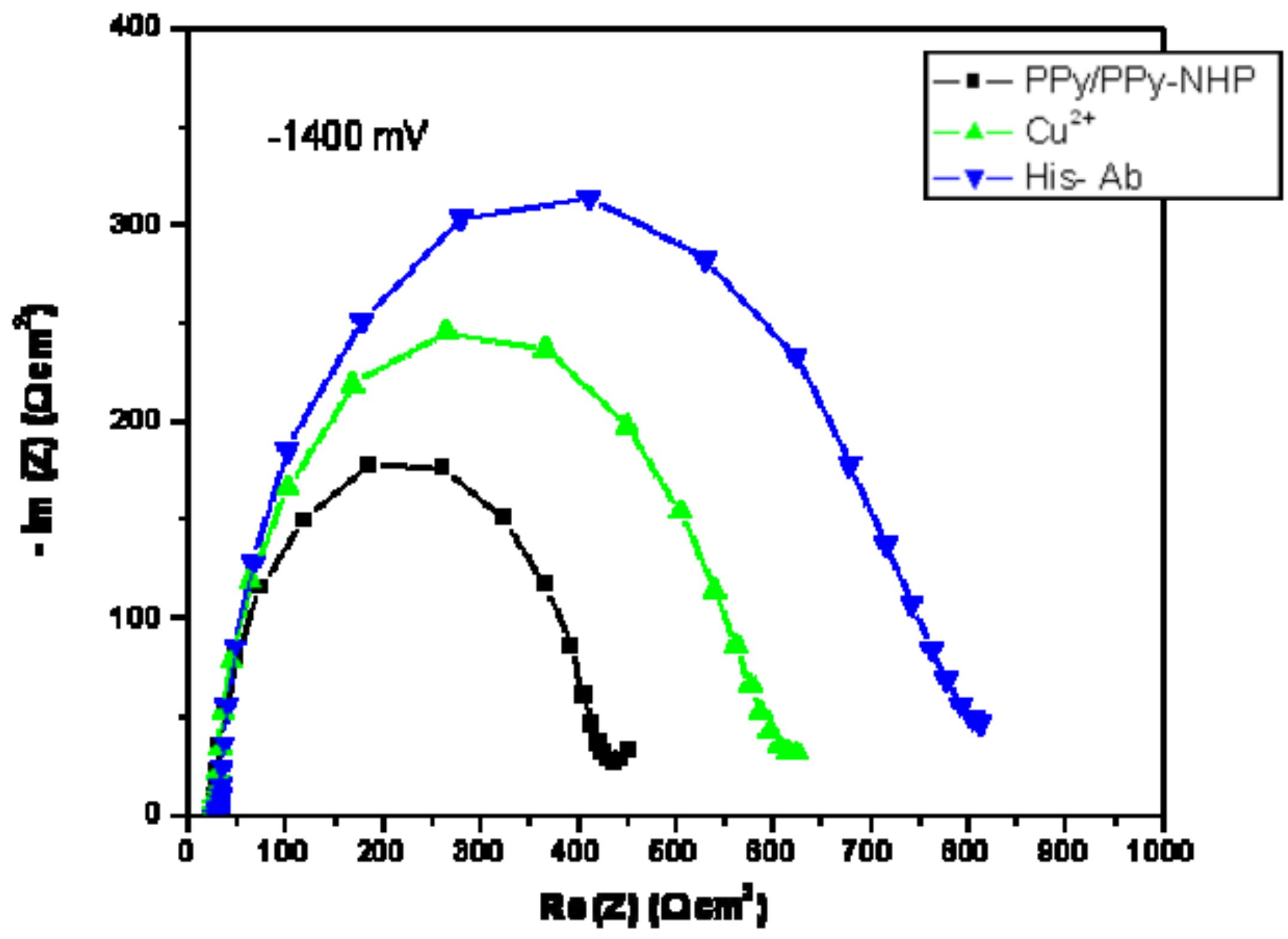




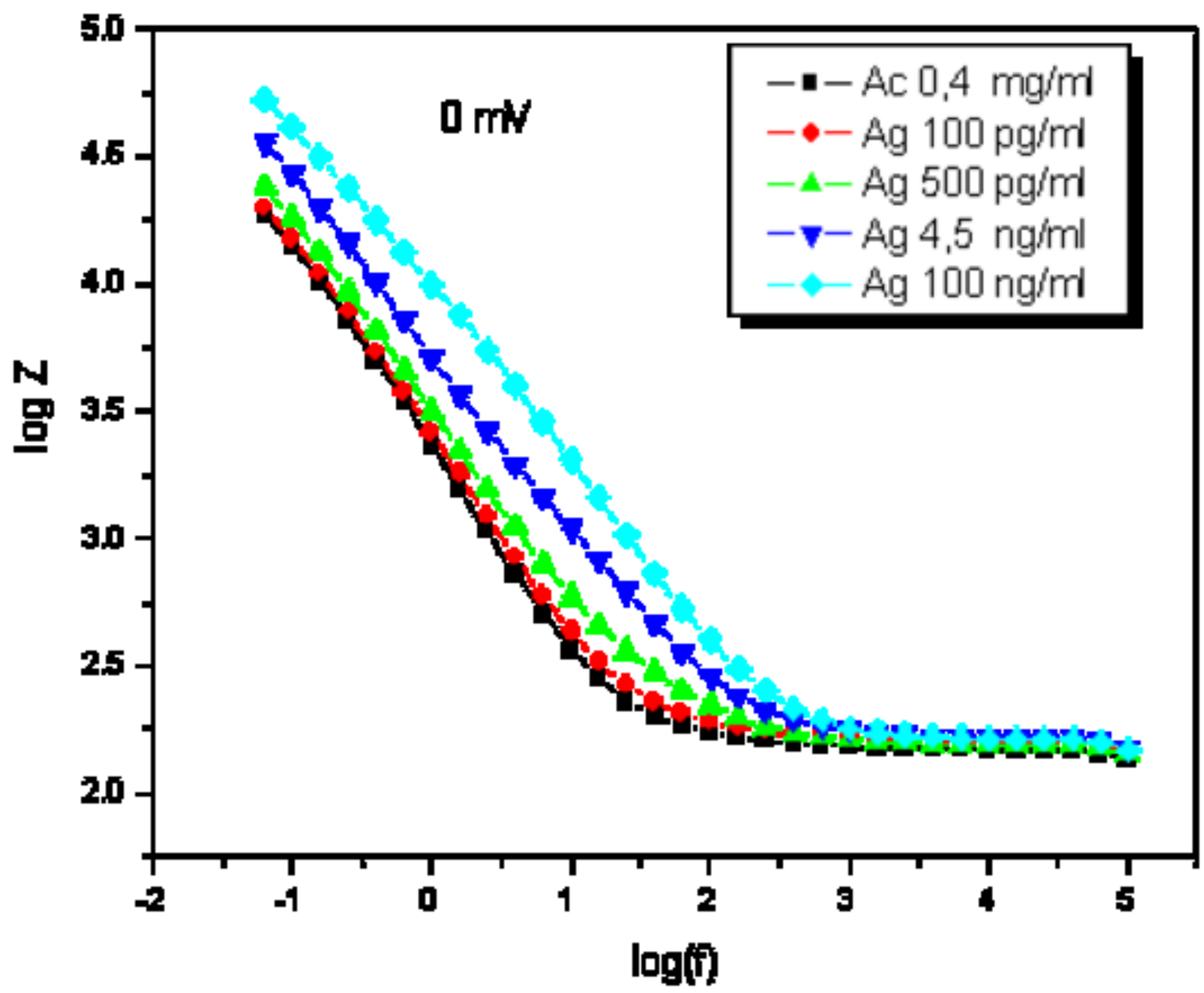




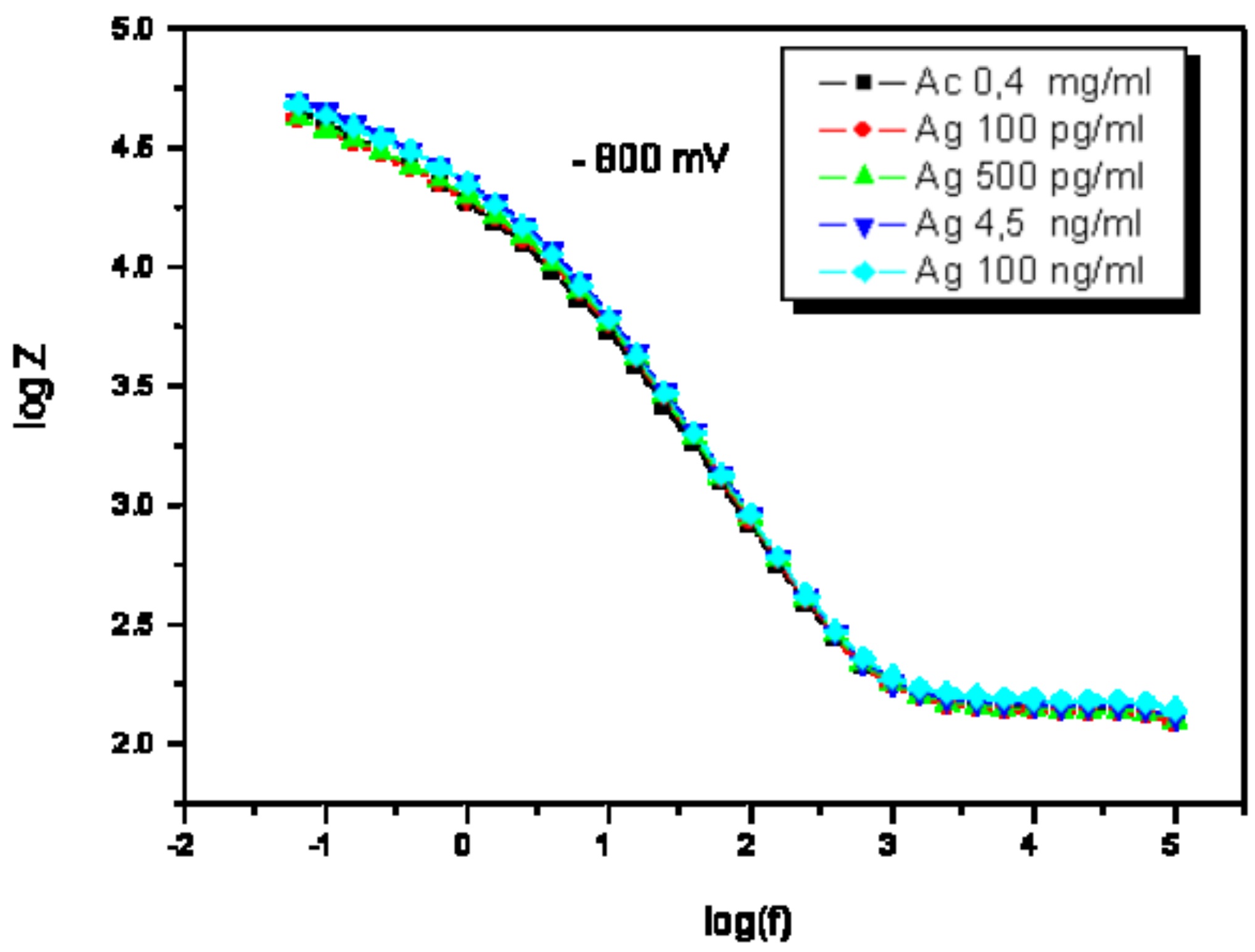




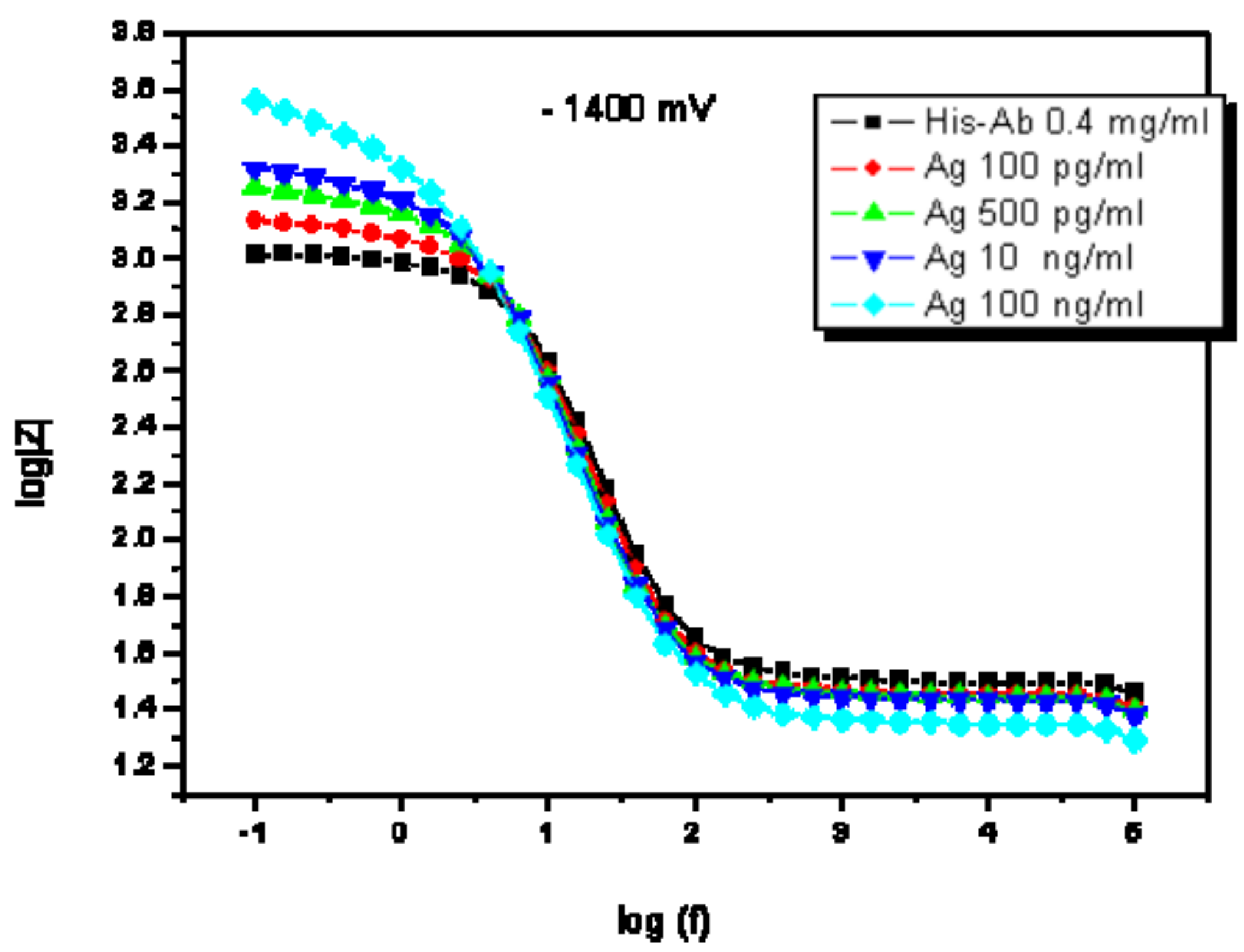




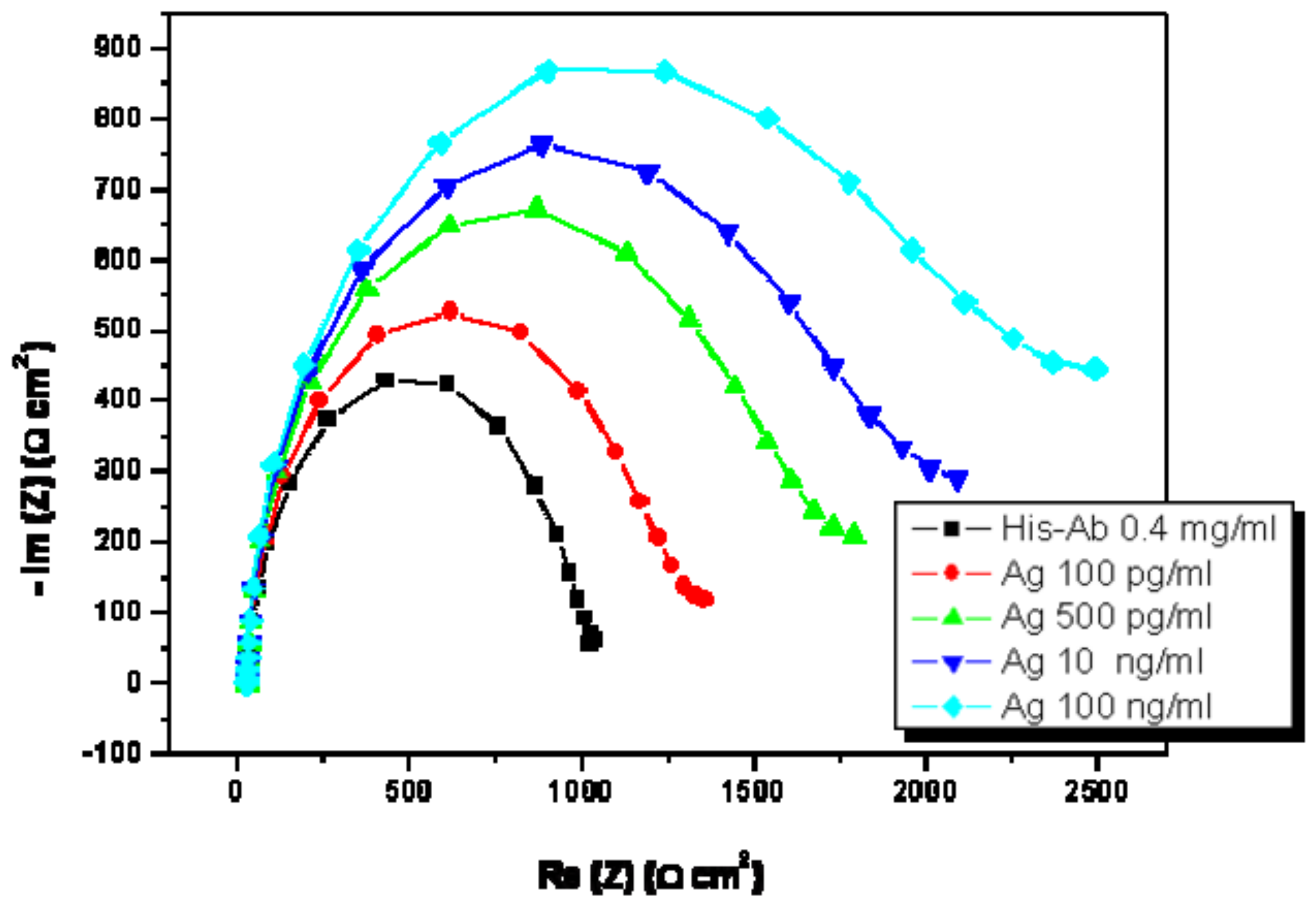




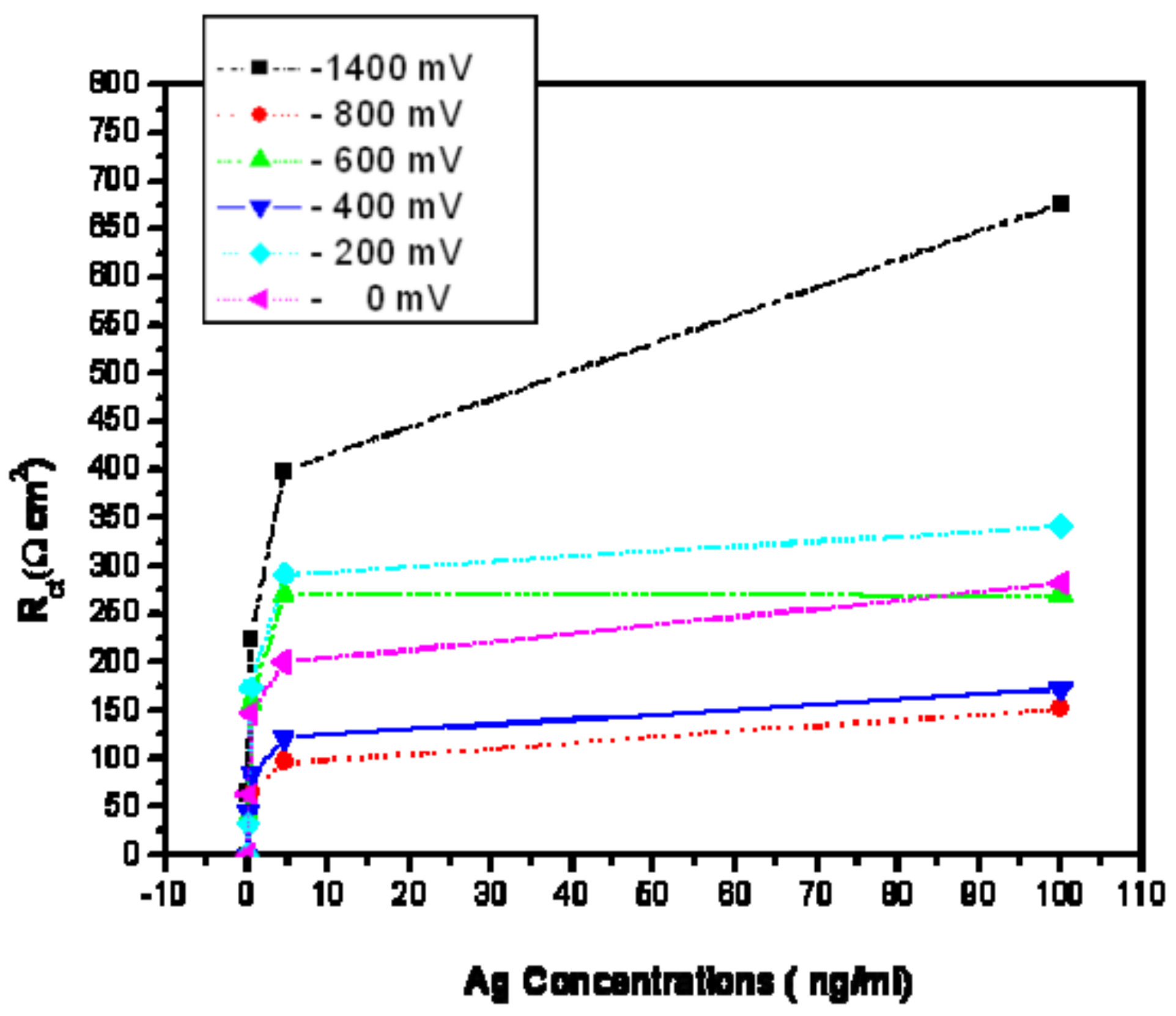




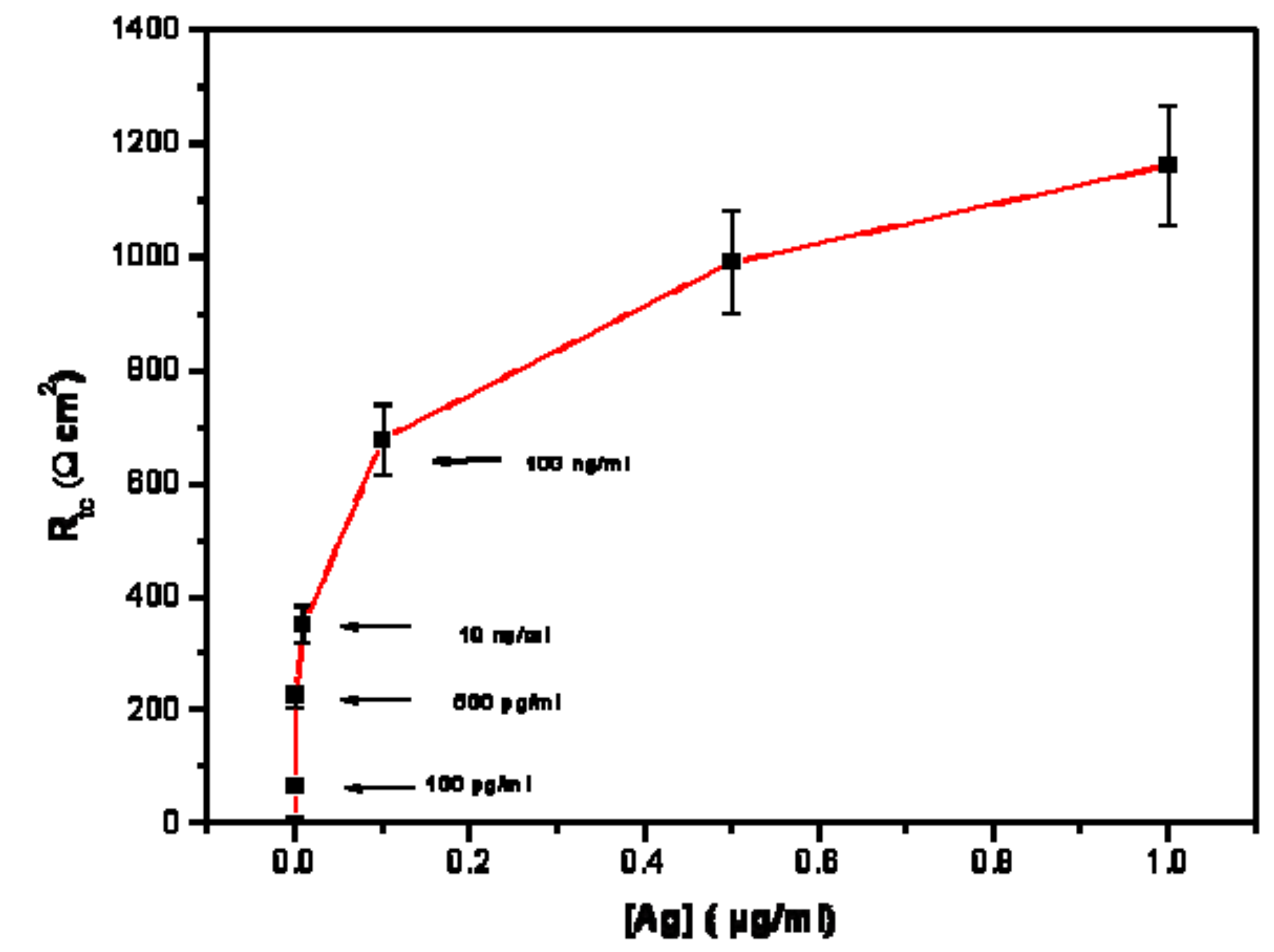

Click here to download high resolution image

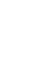




\begin{tabular}{|c|c|c|c|c|c|c|c|c|c|}
\hline $\begin{array}{c}\text { Potential } \\
(\mathrm{m} V)\end{array}$ & Layers & $\begin{array}{c}R s \\
\left(\Omega c m^{2}\right)\end{array}$ & $R f\left(\Omega c m^{2}\right)$ & $C f\left(F c m^{2}\right)$ & $R i / c t\left(\Omega c^{2}\right)$ & $W\left(\Omega c m^{2}\right)$ & $\begin{array}{c}C P E \\
\left(\mathrm{Fcm}^{2}\right)-\end{array}$ & $\alpha_{C P E}$ & $x^{2}$ \\
\hline \multirow{3}{*}{$\mathbf{0}$} & PPY & 38.89 & 11.003 & $1.60 \mathrm{E}-3$ & 7679 & 48789 & $4.10 \mathrm{E}-4$ & 0.81 & 0.0018 \\
\hline & $\mathrm{Cu}^{+2}$ & 35.25 & 58.07 & $1.10 \mathrm{E}-3$ & 7135 & 7550 & $3.60 \mathrm{E}-4$ & 0.82 & 0.0018 \\
\hline & $\mathrm{Ab}$ & 35.01 & 86.56 & $8.50 \mathrm{E}-4$ & 9943 & 10164 & $2.29 \mathrm{E}-4$ & 0.82 & 0.0018 \\
\hline \multirow{3}{*}{-200} & PPY & 37.38 & 24 & $1.73 \mathrm{E}-3$ & 5071 & 7546 & 6.48 E-4 & 0.80 & 0.0012 \\
\hline & $\mathrm{Cu}^{+2}$ & 29.09 & 73 & $4.07 \mathrm{E}-3$ & 4877 & 13456 & $3.40 \mathrm{E}-4$ & 0.81 & 0.0015 \\
\hline & $\mathrm{Ab}$ & 26.92 & 23 & $1.38 \mathrm{E}-3$ & 7793 & 12250 & $1.61 \mathrm{E}-4$ & 0.86 & 0.0019 \\
\hline \multirow{3}{*}{-400} & PPY & 37.24 & 78 & $1.01 \mathrm{E}-3$ & 5506 & 9205 & $2.04 \mathrm{E}-4$ & 0.87 & 0.0021 \\
\hline & $\mathrm{Cu}^{+2}$ & 28.9 & 87 & $9.10 \mathrm{E}-4$ & 4225 & 10184 & $1.85 \mathrm{E}-4$ & 0.88 & 0.0021 \\
\hline & $\mathrm{Ab}$ & 27.2 & 97 & $9.40 \mathrm{E}-4$ & 6749 & 9806 & $1.50 \mathrm{E}-4$ & 0.85 & 0.0022 \\
\hline \multirow{3}{*}{-600} & PPY & 36.51 & 181 & $1.61 \mathrm{E}-4$ & 4150 & 7581 & $1.53 \mathrm{E}-4$ & 0.87 & 0.0021 \\
\hline & $\mathrm{Cu}^{+2}$ & 28.78 & 168 & $1.50 \mathrm{E}-4$ & 4520 & 9121 & $1.51 \mathrm{E}-4$ & 0.79 & 0.0019 \\
\hline & $\mathrm{Ab}$ & 26.91 & 160 & $2.10 \mathrm{E}-4$ & 4901 & 9357 & $1.00 \mathrm{E}-4$ & 0.78 & 0.0023 \\
\hline \multirow{3}{*}{-800} & PPY & 35.31 & 224 & $1.26 \mathrm{E}-4$ & 3202 & 5683 & $3.04 \mathrm{E}-5$ & 0.87 & 0.0013 \\
\hline & $\mathrm{Cu}+2$ & 28.02 & 284 & $2.50 \mathrm{E}-4$ & 3102 & 12040 & $1.89 \mathrm{E}-5$ & 0.91 & 0.0014 \\
\hline & $\mathrm{Ab}$ & 25.75 & 253 & $2.24 \mathrm{E}-4$ & 3402 & 14100 & $1.80 \mathrm{E}-5$ & 0.92 & 0.0012 \\
\hline \multirow{3}{*}{-1400} & PPY & 27.53 & 355.8 & 3.60 E- 5 & 136 & 64.07 & 6.77 E-5 & 0.90 & 0.0019 \\
\hline & $\mathrm{Cu}^{+2}$ & 26.51 & 325.8 & 2.84 E-5 & 212.1 & 64.99 & $1.57 \mathrm{E}-4$ & 0.91 & 0.0020 \\
\hline & $\mathrm{Ab}$ & 27.73 & 473.6 & $2.51 \mathrm{E}-5$ & 272.6 & 81.11 & $2.59 \mathrm{E}-4$ & 0.89 & 0.0016 \\
\hline
\end{tabular}

Table 1 


\begin{tabular}{|c|c|c|c|c|c|c|c|c|c|}
\hline $\begin{array}{c}\text { Potential } \\
(\mathrm{m} V)\end{array}$ & $\begin{array}{c}A g \\
\text { Concentration }\end{array}$ & $\begin{array}{c}R s \\
\left(\Omega \mathrm{cm}^{2}\right)\end{array}$ & $R f\left(\Omega c m^{2}\right)$ & $C f\left(\mathrm{Fcm}^{2}\right)$ & $\operatorname{Rct}\left(\Omega \mathrm{cm}^{2}\right)$ & $\begin{array}{c}W \\
\left(\Omega \mathrm{cm}^{2}\right)\end{array}$ & $C P E\left(F \mathrm{Fm}^{2}\right)-$ & $\alpha_{C P E}$ & $\chi^{2}$ \\
\hline \multirow{5}{*}{0} & 0 & 28.01 & 12.30 & $1.57 \mathrm{E}-4$ & 6165 & 1960 & $5.40 \mathrm{E}-4$ & 0.87 & 0.0022 \\
\hline & $100 \mathrm{pg} / \mathrm{ml}$ & 29.68 & 12.50 & $7.81 \mathrm{E}-5$ & 6229 & 2047 & $4.24 \mathrm{E}-4$ & 0.85 & 0.0015 \\
\hline & $500 \mathrm{pg} / \mathrm{ml}$ & 29.33 & 18.99 & $1.91 \mathrm{E}-4$ & 6313 & 6017 & $3.78 \mathrm{E}-4$ & 0.80 & 0.0021 \\
\hline & $4.5 \mathrm{ng} / \mathrm{ml}$ & 30.89 & 29.51 & $2.71 \mathrm{E}-4$ & 6365 & 16491 & $2.50 \mathrm{E}-4$ & 0.76 & 0.0014 \\
\hline & $100 . \mathrm{ng} / \mathrm{ml}$ & 29.66 & 44.10 & $1.64 \mathrm{E}-4$ & 6447 & 19933 & $1.59 \mathrm{E}-4$ & 0.74 & 0.0016 \\
\hline \multirow{5}{*}{-200} & 0 & 27.61 & 53.80 & $1.06 \mathrm{E}-2$ & 5025 & 19327 & $6.03 \mathrm{E}-4$ & 0.84 & 0.0022 \\
\hline & $100 \mathrm{pg} / \mathrm{ml}$ & 29.02 & 48.60 & $1.98 \mathrm{E}-3$ & 5050 & 12327 & $5.08 \mathrm{E}-4$ & 0.79 & 0.0019 \\
\hline & $500 \mathrm{pg} / \mathrm{ml}$ & 28.22 & 58.48 & $1.07 \mathrm{E}-3$ & 5198 & 13188 & $2.85 \mathrm{E}-4$ & 0.71 & 0.0015 \\
\hline & $4.5 \mathrm{ng} / \mathrm{ml}$ & 28.72 & 94.90 & $1.07 \mathrm{E}-3$ & 5317 & 20296 & $1.71 \mathrm{E}-4$ & 0.70 & 0.0024 \\
\hline & $100 . \mathrm{ng} / \mathrm{ml}$ & 29.01 & 80.70 & $1.60 \mathrm{E}-3$ & 5367 & 23943 & $2.98 \mathrm{E}-4$ & 0.70 & 0.0023 \\
\hline \multirow{5}{*}{-400} & 0 & 26.66 & 96.31 & $2.46 \mathrm{E}-5$ & 4864 & 9771 & $4.60 \mathrm{E}-4$ & 0.87 & 0.0017 \\
\hline & $100 \mathrm{pg} / \mathrm{ml}$ & 27.23 & 102.36 & 4.27 E-5 & 4919 & 8923 & $2.91 \mathrm{E}-4$ & 0.82 & 0.0020 \\
\hline & $500 \mathrm{pg} / \mathrm{ml}$ & 26.11 & 83.10 & $1.16 \mathrm{E}-4$ & 4948 & 11103 & $1.74 \mathrm{E}-4$ & 0.69 & 0.0023 \\
\hline & $4.5 \mathrm{ng} / \mathrm{ml}$ & 28.19 & 82.00 & $5.65 \mathrm{E}-5$ & 4986 & 9709 & $8.14 \mathrm{E}-5$ & 0.77 & 0.0020 \\
\hline & $100 . \mathrm{ng} / \mathrm{ml}$ & 27.53 & 97.30 & $3.67 \mathrm{E}-5$ & 5036 & 8943 & $6.27 \mathrm{E}-5$ & 0.80 & 0.0026 \\
\hline \multirow{5}{*}{-600} & 0 & 27.42 & 108.72 & $3.40 \mathrm{E}-5$ & 4595 & 10469 & $2.10 \mathrm{E}-4$ & 0.79 & 0.0020 \\
\hline & $100 \mathrm{pg} / \mathrm{ml}$ & 26.98 & 145.90 & 7.48 E-5 & 4634 & 10100 & $1.00 \mathrm{E}-4$ & 0.78 & 0.0021 \\
\hline & $500 \mathrm{pg} / \mathrm{ml}$ & 26,45 & 134.50 & $3.34 \mathrm{E}-5$ & 4754 & 14008 & $4.84 \mathrm{E}-5$ & 0.83 & 0.0025 \\
\hline & $4.5 \mathrm{ng} / \mathrm{ml}$ & 28.55 & 125.70 & $4.74 \mathrm{E}-5$ & 4866 & 19203 & $3.20 \mathrm{E}-5$ & 0.87 & 0.0019 \\
\hline & $100 . \mathrm{ng} / \mathrm{ml}$ & 27.00 & 123 & 3.56 E-5 & 4865 & 22277 & $2.27 \mathrm{E}-5$ & 0.88 & 0.0024 \\
\hline \multirow{5}{*}{-800} & 0 & 26,02 & 150 & $2.17 \mathrm{E}-5$ & 3920 & 24100 & $6.04 \mathrm{E}-5$ & 0.82 & 0.0023 \\
\hline & $100 \mathrm{pg} / \mathrm{ml}$ & 26.87 & 198 & $2.18 \mathrm{E}-5$ & 3957 & 25588 & $6.08 \mathrm{E}-5$ & 0.83 & 0.0024 \\
\hline & $500 \mathrm{pg} / \mathrm{ml}$ & 26.82 & 134 & $2.19 \mathrm{E}-5$ & 3986 & 28869 & $5.83 \mathrm{E}-5$ & 0.82 & 0.0024 \\
\hline & $4.5 \mathrm{ng} / \mathrm{ml}$ & 28.18 & 130 & $2.34 \mathrm{E}-5$ & 4016 & 45289 & $4.90 \mathrm{E}-5$ & 0.83 & 0.0023 \\
\hline & $100 . \mathrm{ng} / \mathrm{ml}$ & 29.45 & 189 & $1.45 \mathrm{E}-5$ & 4072 & 52910 & $4.93 \mathrm{E}-5$ & 0.79 & 0.0025 \\
\hline \multirow{5}{*}{-1400} & 0 & 28.38 & 284.1 & $2.78 \mathrm{E}-5$ & 214.4 & 44.03 & $1.86 \mathrm{E}-4$ & 0.90 & 0.0017 \\
\hline & $100 \mathrm{pg} / \mathrm{ml}$ & 29.14 & 217.7 & $3.48 \mathrm{E}-5$ & 279.9 & 44.02 & $1.20 \mathrm{E}-4$ & 0.89 & 0.0018 \\
\hline & $500 \mathrm{pg} / \mathrm{ml}$ & 27.72 & 338.7 & $3.17 \mathrm{E}-5$ & 438.4 & 78.25 & $1.49 \mathrm{E}-4$ & 0.87 & 0.0017 \\
\hline & $10 \mathrm{ng} / \mathrm{ml}$ & 27.73 & 302.5 & $3.42 \mathrm{E}-5$ & 614.4 & 119.5 & $9.74 \mathrm{E}-5$ & 0.86 & 0.0018 \\
\hline & $100 . \mathrm{ng} / \mathrm{ml}$ & 26.58 & 308.6 & $3.84 \mathrm{E}-5$ & 891.4 & 195.4 & $7.71 \mathrm{E}-5$ & 0.87 & 0.0017 \\
\hline
\end{tabular}

Table 2

\begin{tabular}{clcll}
\hline Potential $(\mathbf{m V})$ & $\begin{array}{l}\text { Sensitivity } \\
\left(\boldsymbol{\Omega} \boldsymbol{c m}^{2} / \boldsymbol{\mu g}{\left.\mathbf{~} \mathbf{L}^{-1}\right)}\right.\end{array}$ & Detection limit & $\begin{array}{l}\text { Dynamic } \\
\text { measurement }\end{array}$ & $\begin{array}{l}\text { Coefficient } \\
\text { regression } \mathbf{R}^{2}\end{array}$ \\
\hline $\mathbf{0}$ & $2.9210^{5}$ & $62.7 \mathrm{pg} / \mathrm{mL}$ & $0-500 \mathrm{pg} / \mathrm{mL}$ & 0.950 \\
$\mathbf{- 2 0 0}$ & $3.510^{5}$ & $40.0 \mathrm{pg} / \mathrm{mL}$ & $0-500 \mathrm{pg} / \mathrm{mL}$ & 0.996 \\
$\mathbf{- 4 0 0}$ & $4.110^{5}$ & $32.0 \mathrm{pg} / \mathrm{mL}$ & $0-100 \mathrm{pg} / \mathrm{mL}$ & 0.986 \\
$\mathbf{- 6 0 0}$ & $3.110^{5}$ & $37.7 \mathrm{pg} / \mathrm{mL}$ & $0-500 \mathrm{pg} / \mathrm{mL}$ & 0.997 \\
$\mathbf{- 8 0 0}$ & $3.710^{5}$ & $40.2 \mathrm{pg} / \mathrm{mL}$ & $0-100 \mathrm{pg} / \mathrm{mL}$ & 0.997 \\
$\mathbf{- 1 4 0 0}$ & $4.310^{5}$ & $21.4 \mathrm{pg} / \mathrm{mL}$ & $0-10 \mathrm{ng} / \mathrm{mL}$ & 0.990 \\
\hline
\end{tabular}

Table 3 
